\title{
Customer Efficiency, Channel Usage and Firm Performance in Retail Banking
}

Mei Xue

Operations and Strategic Management Department

The Wallace E. Carroll School of Management Boston College

350 Fulton Hall, 140 Commonwealth Avenue

Chestnut Hill, MA 02467

Phone: (617)552 -6821 - Fax: (617)552-0433

xueme@bc.edu

Lorin M. Hitt

Operations and Information Management Department

The Wharton School

University of Pennsylvania

571 John Huntsman Hall

Philadelphia, PA 19104

Tel: 215-898-7730 • Fax: 215-898-3664

lhitt@wharton.upenn.edu

Patrick T. Harker

Operations and Information Management Department

The Wharton School

University of Pennsylvania

1000 SHDH, 3620 Locust Walk

Philadelphia, PA 19104-6364

Phone: (215) 898-4715 • Fax: (215) 573-5001

harker@wharton.upenn.edu

Forthcoming in Manufacturing \& Service Operations Management

(http://msom.pubs.informs.org/) 


\section{Customer Efficiency, Channel Usage and Firm Performance in Retail Banking}

Innovations in technology and service design have increasingly enabled firms to incorporate selfservice technology to augment or substitute for "traditional” employee-provided service channels. Although it is clear that self-service can reduce cost, less is known about how customers utilize self-service channels in a multi-channel service delivery system and the resulting impact on firm performance. An important aspect of service operations is that customers are co-producers of the service. Thus, the performance of the delivery system and customers' use of service channels can be affected by customers' own efficiency or productivity in service co-production (customer efficiency). In this paper we utilize prior theoretical frameworks in service operations and economics to hypothesize relationships among customer characteristics (especially co-production efficiency), channel utilization, and firm performance. We then test these hypotheses using panel data from a large retail bank. Overall, we find that higher customer efficiency in selfservice channels is associated with greater profitability and has a complex relationship with customer retention and product utilization.

Key words: service operations management, service delivery system, self-service technology (SST), service co-production, customer efficiency.

\section{Introduction}

Customer participation has always been an indispensable part of any service delivery process (Chase, 1978, Lovelock and Young, 1979, Karmarkar and Pitbladdo, 1995). In many processes, the labor of the customers and the employees of the firm are, to some extent, substitutable. Although self-service has long been an alternative to full service by employees in many industries (e.g., gas stations), the development of new information technologies and innovations in product design have led to an unprecedented increase in the scale and scope of self-service utilization. Around the world, millions of consumers use the Internet for shopping, managing bank accounts, trading stocks, booking flights, buying movie tickets, tracking packages, and selling everything from a silver spoon to a used car. The profound impact of this proliferation of self-service is evident in almost all major service industries. 
In this wave of the so-called "self-service revolution," a multi-channel service delivery system that combines a portfolio of employee and self-service channels in both physical and virtual environments has become the dominant model, replacing systems that rely primarily on employee service delivered in physical channels. Figure 1 shows such a multi-channel service delivery system in retail banking. Similar systems can also be found in the transportation and retail sectors. The popularity of self-service is a result of decades of service delivery innovation in pursuit of lower costs and higher quality, fueled by the advancement of technology, especially information technology. In some industries, especially in the Western world, the provision of such a multi-channel service delivery system has become a competitive necessity (The Banker, 2003). Moreover, service delivery systems can have a significant effect on firms' operations strategy such as capacity management (Roth and Menor 2003, Ellram et al. 2004), as well as on the operational performance of other business processes that directly interact with the customer, such as sales and marketing.

The appeal of adding customer self-service to the overall service delivery mix is straightforward. By offloading tasks onto customers and enabling them to pursue their own service needs, firms can often provide customized services at mass production cost levels. In addition, many of the technologies underlying self-service, such as Internet-based ordering or customer support, also enjoy significant economies of scale while providing greater access, flexibility and convenience. 


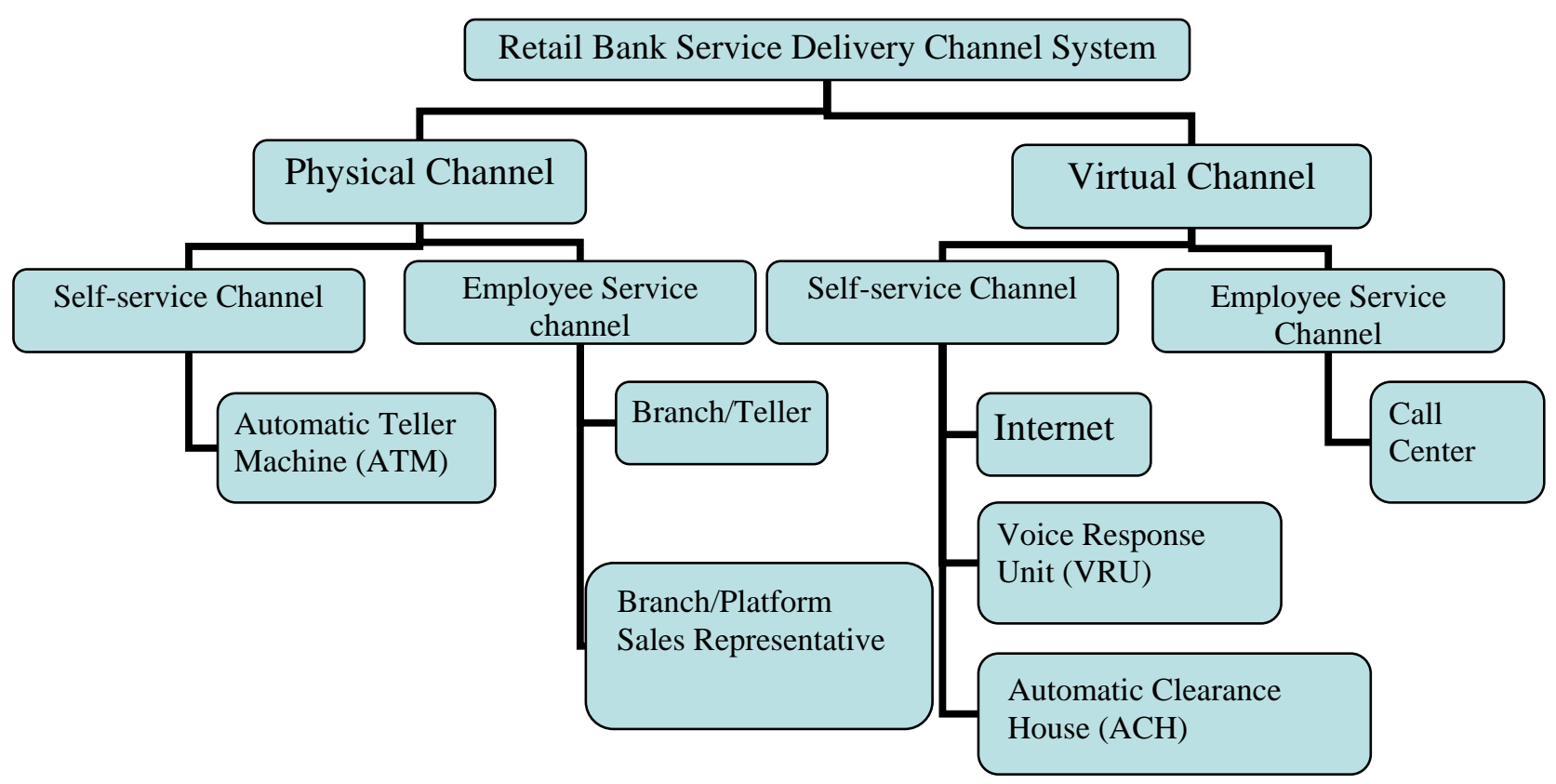

Figure 1: The Multi-Channel Service Delivery System in Retail Banking

In a world in which a significant number of customers obtain their service from multiple service channels, the design and management of such a system requires understanding of how customers decide which channels to utilize and how these choices affect both the optimal design of service delivery systems as well as related business processes. For instance, the widespread adoption of Internet banking has required changes of traditional banks in the service capacity and skill requirements of call center representatives (e.g., to provide computer technical support), the design of different types of banking products to compete against the online-only banks, the approaches used to cross-sell or up-sell incremental banking products, the distribution of physical service channels such as ATMs and branches, and the mitigation of potential new risks such as online identity theft. These interdependencies have caused firms to recognize that without an integrated perspective on channel utilization, firms may miss opportunities for better resource allocation, improved operational performance, and stronger customer relationships.

Management of the performance of self-service channels presents an unusual problem in that the performance of the service system is affected by the actions of the customers with uncertain capabilities, incentives and goals. Thus, customers' own actions and cognitive abilities can have 
a greater impact on service quality in self-service channels than in employee service channels. Moreover, because customers are generally free to choose the channels in which they obtain their service, perhaps shaped by incentives from the service provider, uncertainty in overall customer use of a channel can be further compounded by uncertainty in customer behavior (Davis 1993, Ellram et al. 2004). Some institutions have experimented with denying a subset of customers access to certain channels, such as access to bank branches or other high cost services. Often, however, these innovations were either misunderstood or rejected by consumers. In some industries, such as airlines and retail brokerage, explicit price incentives for channel use have been implemented (e.g., a booking fee for use of a human ticket agent), although uncertainty about customer reaction to explicit pricing for different channels has limited the diffusion of these types of practices. Despite these difficulties, many financial institutions are continuing to experiment with a variety of methods to encourage customers to utilize the "right" channel for their service needs.

The focus of this study is to provide an empirical analysis of the determinants of self-service use, and how customers' channel choices are associated with firm performance. Utilizing insights from prior models of service operations (Huete and Roth 1988, Roth 2001, Boyer et al. 2002, Heskett et al., 1997), we hypothesize that customers choose among channels to perform these transactions based on the relative costs and benefits they receive from each choice. Because selfservice involves an aspect of co-production, these costs are directly influenced by customer capabilities in self-service channels (or "customer efficiency" as in Xue and Harker (2002)) in addition to other customer and channel characteristics. While this theoretical structure is straightforward, it is unclear which factors, both absolutely and relatively, are important in determining service demand. Therefore, our first of two major research questions is: "What drives a customer's use of different channels in a multi-channel service delivery system?”

Second, although customers make their channel choice decisions based on their own costs and benefits of using different channels, their decisions may not necessarily maximize the profits of the service provider. Given that most organizations have made only limited efforts to influence customer channel choice and that customers are heterogeneous, we have the opportunity to observe the effects on the firm of a wide array of individual channel choices. The aggregate 
results of these individual customer behaviors affect critical dimensions of firm performance such as customer profitability, customer retention and product adoption. This leads us to our second major research question, "How does customers' channel use influence firm performance?”

A key empirical challenge of this work is to measure customer efficiency. Xue and Harker (2002) developed a customer efficiency measurement framework that utilizes direct measures of customer inputs (e.g. time, effort) and output. However, this approach cannot be directly applied when customer inputs are hard to measure (especially if some costs are intangible) or when firms seek to measure efficiency using archival data that did not include direct measures of customer costs (e.g., data in transaction processing systems). In this paper, we present an alternative approach in which we infer customer efficiency by revealed channel choice. After accounting for non-customer factors such as channel availability (e.g., location) and factors unrelated to service co-production efficiency (e.g., transaction requirements), customers who concentrate their activity in self-service channels when a full-service alternative is available for the same transaction are inferred to be more efficient. We can partially validate this measure by comparing it to factors such as education and experience, which should be associated with efficiency in our empirical setting, and we also incorporate this measure into models that predict performance.

We test our hypotheses using a panel dataset of monthly transaction data for approximately 25,000 customers of a large retail bank from July 2002 to June 2003. Our data include detailed observations on transaction activity, customer demographic information, and customer profitability, loyalty and product adoption measures. Overall, our results suggest that there is considerable variation in revealed customer efficiency and that customers with higher measured efficiency tend to be younger, have more education, and be more experienced with computers and banking services in general, which is consistent with our prior expectations. We also find that other factors, unrelated to customer efficiency, also affect channel choice, which suggests that our measure of customer efficiency is related to but distinct from a customer's overall use of self-service itself. Second, customers who appear to be more efficient have greater profitability. and utilize more bank services and have a lower chance to leave the bank, although the effects of 
customer efficiency on product adoption and retention seem to have diminishing returns. Overall, this suggests that our concept of customer efficiency is relevant for understanding customer channel choice as well as customer profitability and, therefore, has the potential to be productively used in practice for understanding customer channel choices and incorporating these choices into the design of service delivery systems.

\section{Literature Review}

\subsection{Self-Service and Service Operations}

The role of the customer as a "co-producer" in service operations has a long history in service operations management. Fuchs (1968) notes that customers are always either passively or actively involved in the service production process. Subsequent research on service operations management recognized the interaction between the customer and firm (Chase 1978) and the importance of integrating the production role of customers into the design of service delivery systems (Globerson and Maggard 1991). Prior research has also noted that the design of these self-service delivery systems can have significant competitive implications (Karmarkar and Pitbladdo 1995, Heskett et al. 1997).

With customers as co-producers, it is increasingly important to understand and manage customers' service choices and their performance in service production activities. Lovelock and Young (1979) utilize case analysis to demonstrate that developing service systems that account for customer needs and preferences is essential to realizing productivity gains from self-service operations. Subsequent work identified the factors which drive customers' decisions to use selfservice channels, namely time, control, effort, dependence, efficiency, and human contact (Bateson 1985). Other research has suggested parallels between managing customers and managing employees, using insights from human resource management (Bowen 1986, Kelley et al. 1990). Combining insights from the prior literature on service co-production with approaches from efficiency analysis, Xue and Harker (2002) propose the concept of "customer efficiency" to capture the notion that customers may vary in their ability to effectively participate in selfservice, which in turn affects both customer outcomes (e.g., satisfaction, perceived cost) as well as firm profitability. 
Self-service systems are more than just a standalone feature of the organization. The literature has increasingly focused on the observation that self-service systems need to be integrated with other aspects of organizational design. As Roth and Menor (2003: 151) observe: “Central to service delivery system design is explicit consideration of the nature of customer contacts (e.g., face-to-face, electronically mediated, and back-office support interactions).” Whereas these issues have long been part of customer contact theory (Chase 1978, 1981, Kellogg and Chase, 1995, Soteriou and Chase 1998), new types of self-service channels introduced new considerations into these approaches. For instance, recent work considered how electronically mediated (or "virtual”) service activities interact with traditional face-to-face service approaches (Froehle and Roth 2004) and how these new service options affect strategies for market positioning and customer relationship management (Voss 2000).

In this literature stream, our work is most closely related to the Service Strategy Design Matrix (Huete and Roth 1988), the Product-Process-Proximity ( $p^{3}$ ) Matrix for Services (Boyer, Hallowell, and Roth 2002), the E-service Customer Retention Model (Roth 2001), the Service Profit Chain model (Heskett et al. 1997), and the Customer Efficiency Management (CEM) framework (Xue and Harker 2002). Our model extends the Service Strategy Design Matrix and the $p^{3}$ model framework by modeling customer choice of delivery channel in a multi-channel system, while the $p^{3}$ model focuses on firm choice of delivery channel by addressing the tradeoffs between industrialization level (technical mediation level at the customer touch point) and customization. Our model also extends the E-service customer retention model (Roth 2001) by extending the setting from a single channel (Internet) to a multi-channel service delivery system with both physical and virtual employee service and self-service channels.

Xue and Harker (2002) propose the "customer efficiency” concept to study the role and impact of a customer as a co-producer in service co-production. An "efficient customer" is one who consumes less resource to produce more or the same amount of output in her participation in the service co-production process. In essence, the concept of customer efficiency parallels the classical concept of employee productivity. However, the "dual roles” of a customer (both as coproducer and as consumer) imply an important distinction between a firm view of efficiency (the firm's benefits versus firm costs for facilitating and supporting the customer's co-production 
activity) versus a customer view of efficiency (the customer's value versus direct costs and opportunity costs faced by the customer for conducting the co-production activity). Xue and Harker (2002) also note that coordinating service design with other complementary firm decisions (e.g., marketing and product or service design) to build an efficient customer base can have significant impact on operational performance, a process they refer to as customer efficiency management (CEM).

\subsection{Online Service in Financial Services}

Prior work has also explicitly examined the role of the Internet as a distribution channel in the financial services industry. Apte and Vepsalainen (1993) examined the tradeoff between using "high tech" versus "high touch" channels and argued that the former is effective for cost reduction and the latter is more effective for relationship building. Roth and Jackson III (1995) found a negative correlation between total factor productivity and service quality, which underscores the importance of cost-benefit tradeoffs in service design. Menor et al. (2001) showed that operations agility, which is defined as the ability to excel simultaneously on operations capabilities of quality, delivery, flexibility and cost, is as vital for retail banks' performance as it is for manufacturing firms. Hitt and Frei (2002) examined customer behavior using in retail banks and found that customers who utilize online banking used more products and were more profitable, but that these differences existed prior to the adoption of online banking. However, this study did not consider channel usage. Chen and Hitt (2002) showed that customer retention in the online brokerage industry can be influenced by the design of selfservice systems and other product design choices. Choi et al. (2005) presented a modeling framework for service delivery in retail banking, examining how two alternative service delivery processes (conventional and electronic) affect customer costs, process economics, market segmentation, and competition.

\subsection{Customer Efficiency and Firm Performance}

Prior literature suggests a positive link between customer efficiency and firm performance such as profitability and loyalty for two major reasons. First, the lower cost of operating self-service channels than employee service channels offers the opportunity of significant cost savings 
(Chase 1978, 1981, Lovelock and Young 1979, Heskett et al., 1997, Bitner et al. 1997). Second, a more efficient customer gains greater value from self-service (Xue and Harker 2002), which, in turn, encourages greater product adoption and a longer relationship length (Roth 2001, Xue and Harker 2002).

However, while efficient customers may realize greater value from their service interactions and more extensively utilize low-cost channels, they may also engage in other behaviors that can negatively impact their loyalty and profitability. Since efficient customers are expected to utilize self-service channels more than employee service channels, the reduced personal contact may undermine the bond between the customer and the service provider and thus reduce customer loyalty (Selnes and Hansen 2001). Also, while self-service channels may present a new sales opportunity, it may come at the expense of reduced contact in employee service channels where sales efforts can be more effective, yielding a "sales penalty” of self-service (Heute and Roth 1988). Efficient customers, with their deeper knowledge of the firm's products, may also be better at optimizing their benefits at the expense of the firm by choosing loss-leader products. Examples of this behavior in retail banking might include minimizing the amount of idle deposits by keeping money only in interest-bearing accounts, or transferring high-cost loans (e.g., credit cards) into credit vehicles with lower interest rates and margins (e.g., home equity lines of credit). Thus, while it is plausible that high efficiency is also associated with higher firm performance, the relationship between customer efficiency and customer profitability is an empirical question.

\section{Model}

\subsection{Measuring Customer Efficiency Using Channel Choice}

When direct measurement of customer inputs and output are possible, customer efficiency can be calculated directly (Xue and Harker 2002). However, when these data cannot be utilized (either because all inputs and outputs are not measurable or not available in archival data), customer efficiency can be inferred from actual customer behavior. Presumably "efficient” customers will conduct more transactions in self-service channels controlling for other factors that affect selfservice choice because of their relatively lower direct labor and opportunity costs. We utilize this insight to develop a simple model that relates channel choice to customer efficiency with 
special attention to measuring variation in efficiency across customers. The model is motivated by our retail banking setting but appears to be consistent with the structure of other multichannel service systems where consumers have discretion over which channels to use for their transactions.

Consider a customer that can use a multi-channel service delivery system consisting of $\mathrm{C}$ different channels, indexed by $\mathrm{c}, \mathrm{c} \in \mathrm{C}=\{1,2, \ldots, \mathrm{C}\}$ to conduct $\mathrm{J}$ possible service or transaction types, indexed $\mathrm{j}, \mathrm{j} \in \mathrm{J}=\{1, \ldots, \mathrm{J}\}$. A customer's cost of labor is $w$ (e.g., time opportunity cost) per unit of input customer labor $\left(L_{c j}\right)$, and the value of the service is $v$ per unit of output $\left(O_{c j}\right)$. Service value is independent of the channel through which the service is acquired but differs by service or transaction type (e.g., deposit, withdrawal, inquiry, account transfer). Thus, a customer's utility of using channel $c$ to conduct $O_{c j}$ of type $j$ transactions is: $u_{c j}=v_{j} O_{c j}-w L_{c j}, j \in J^{c}, c \in C$.

Note $J^{c} \subseteq J$ is the subset of transaction types that can be conducted in channel c. The parameters $w$ and $v$ are assumed exogenous but may vary by customer. Furthermore, assume the total utility of banking services obtained by the customer is the sum of the utility for each individual transaction in each channel. Thus, total utility $\mathrm{U}$ is given by: $U=\sum_{c=1}^{C} u_{c}=\sum_{c=1}^{C} \sum_{j=1}^{J} u_{c j}$. Assuming that there are no production complementarities between activities of different transaction types in different channels $\left(\frac{\partial^{2} O_{c j}}{\partial L_{c j} \partial L_{c^{\prime} j^{\prime}}}=0 \forall c^{\prime} \neq c, j^{\prime} \neq j\right)$, each customer's utility maximization program reduces to a set of independent labor choices across channels for different transaction types. Consequently, we now focus on characterizing the input choices for each channel, allowing each channel to have a different value, production function, or set of input quantities. Because the quantity of transactions of a given type are principally determined by daily life events, we assume that total numbers of transactions are exogenous, although the customer is free to allocate her transactions across channels (thus, $O_{c j}, j \in J^{c}, c \in C$ are choices subject to the constraint $O_{j}=\sum_{c \in C} O_{c j}, j \in J$ where the $O_{j}$ are exogenous). 
In general, transaction services are produced by a combination of inputs from both consumers and the firm. Let the production inputs for this channel and transaction type be customerinvested capital (R), customer labor (L), firm-invested capital (K), and firm employee labor (H). Assuming that the effects of customer inputs and firm inputs are in multiplicative form, this yields an overall production function for transaction services of type $\mathrm{j}$ in channel c (or output $O_{c j}$ ) of the form:

$O_{c j}=g_{c}\left(R_{c}, L_{c j}\right) f_{c}\left(K_{c}, H_{c}\right)$

Let the customers' portion of the production function take the Cobb-Douglas form, commonly used in production economics: $g_{c}\left(R_{c}, L_{c j}\right)=R_{c}^{\alpha_{c}}\left(A_{c} L_{c j}\right)^{\beta_{c}}$ where $\alpha_{c}, \beta_{c}$ are the output elasticities of customer capital and customer labor, respectively, and ${ }^{A_{c}}$ is a customer-specific factor that affects the customer's productivity of labor when using channel c Note that this representation differs slightly from the usual Cobb-Douglas form which places the productivity term as a multiplier of both capital and labor $O=A_{0} R^{\alpha} L^{\beta}$. The two representations are equivalent because $A_{0}=A^{\beta}$. We utilize this non-standard representation to make it clear that our hypothesized cause of variations in customer efficiency is due to variations in customer labor input for a given output.. We represent the mean customer as having $A_{c}=1$, with higher values of $A_{c}$ representing more productive customers, and lower values of $A_{c}$ representing customers who are less productive than the average. Note that the firm portion of the production function, $f_{c}\left(K_{c}, H_{c}\right)$ is likely to be slow changing and does not vary across customers with equal physical access (e.g., geographic location). Therefore, from the perspective of an individual customer, this term is quasi-fixed. Similarly, since customers do not typically change the location of their office or residence due to ATM or branch locations, or invest in a computer solely to utilize online banking, we treat customer capital $\left(R_{c}\right)$ as quasi-fixed as well. In this formulation, a customer then chooses an effort level for each channel (which determines the usage of each channel) to solve:

$$
\max _{L_{c}} U_{c}=\max _{L_{c}} \sum_{j=1}^{J^{c}} u_{c j}=\max _{L_{c}} \sum_{j=1}^{J^{c}}\left(v_{j} O_{c j}-w L_{c j}\right)=\sum_{j=1}^{J^{c}} \max _{L_{c j}}\left(v_{j} O_{c j}-w L_{c j}\right),
$$


where $L_{c}=\left(L_{c 1}, \ldots, L_{c 2}, \ldots, L_{c J^{c}}\right)$ is the vector of customer labor input for $J^{c}$ different types of transaction using channel c. This problem yields a set of first order conditions in which the marginal product of labor equals the wage rate $(w): L_{c j}{ }^{*}=\left(L_{c j} \mid \frac{\partial O_{c j}}{\partial L_{c j}}=\frac{w}{v_{j}}\right)$.

Substituting the form of the production function for $\mathrm{O}$ and differentiating with respect to labor input yields the first order condition: $\frac{\partial O_{c j}}{\partial L_{c j}}=\beta_{c} R_{c}^{\alpha_{c}} A_{c}^{\beta_{c}} f_{c}\left(K_{c}, H_{c}\right) L_{c j}^{\beta_{c}-1}$, which implies an optimal labor choice of $L_{c j}^{*}=\left[\frac{\beta_{c} R_{c}^{\alpha_{c}} c_{c}^{\beta_{c}} f_{c}\left(K_{c}, H_{c}\right) v_{j}}{w}\right]^{\frac{1}{1-\beta_{c}}}$. Substituting this back into the original production function yields:

$$
O_{c j}^{*}=R_{c}^{\frac{\alpha_{c}}{1-\beta_{c}}} A_{c}^{\frac{\beta_{c}}{1-\beta_{c}}}\left[f_{c}\left(K_{c}, H_{c}\right)\right]^{\frac{1}{1-\beta_{c}}} V_{j}^{\frac{1}{1-\beta_{c}}} w^{\frac{\beta_{c}}{\beta_{c}-1}}
$$

Because $O_{c}^{*}=\sum_{j=1}^{J^{c}} O_{c j}^{*}$, we have

$$
O_{c}^{*}=R_{c}^{\frac{\alpha_{c}}{1-\beta_{c}}} A_{c}^{\frac{\beta_{c}}{1-\beta_{c}}}\left[f_{c}\left(K_{c}, H_{c}\right)\right]^{\frac{1}{1-\beta_{c}}} w^{\frac{\beta_{c}}{\beta_{c}-1}} \sum_{j=1}^{J^{c}} v_{j}^{\frac{1}{1-\beta_{c}}}
$$

or in logarithms:

$$
\log O_{c}^{*}=\frac{1}{1-\beta_{c}} \log f_{c}\left(K_{c}, H_{c}\right)+\frac{\alpha_{c}}{1-\beta_{c}} \log R_{c}+\frac{\beta_{c}}{1-\beta_{c}} \log A_{c}+\frac{\beta_{c}}{\beta_{c}-1} \log w+\log \left(\sum_{j=1}^{J^{c}} v_{j}^{\frac{1}{1-\beta_{c}}}\right),
$$

Thus, a customer will utilize each channel to produce a number of transactions $O_{c}^{*}$ as a function of customer efficiency $A_{c}$, level of customer capital $R_{c}$, and unit cost of customer labor input $w$, the firm's inputs in the channels, $\left(K_{c}, H_{c}\right)$, and the values of each transaction type, $v=\left(v_{1}, \ldots, v_{j}, \ldots, v_{J^{c}}\right)$. Holding service values and non-efficiency-related customer characteristics as constants, customers will concentrate their transactions in channels with the greater output elasticity of customer labor and capital $\left(\beta_{c}, \alpha_{c}\right)$, and where the overall firm contribution to output $\left[f_{c}\left(K_{c}, H_{c}\right)\right]$ is larger.

The concept of most interest in this model is the variation in customer efficiency across customers. Hypothetically, if we could run a regression of transaction count on a constant, plus measures of customer effort costs $(w)$, transaction value $\left(v_{j}\right)$ and customer capital $\left(R_{c}\right)$, we 
could retrieve the efficiency measures as the residual of that equation. This is the approach used in the empirical production economics literature for the computation of multifactor productivity (see e.g., Griliches 1994). Formally, consider an empirical model of the form:

$$
\log O_{c}^{*}=\frac{1}{1-\beta_{c}} \log f_{c}\left(K_{c}, H_{c}\right)+\frac{\alpha_{c}}{1-\beta_{c}} \log R_{c}+\frac{\beta_{c}}{\beta_{c}-1} \log w+\log \left(\sum_{j=1}^{J^{c}} v_{j}^{\frac{1}{1-\beta_{c}}}\right)+\varepsilon_{c}
$$

The residual term of Equation (7) $\varepsilon_{c}$ then provides an estimate of the customer efficiency term for each customer: $\varepsilon_{c}=\frac{\beta_{c}}{1-\beta_{c}} \log A_{c}$ or $A_{c}=\left[\exp \left(\varepsilon_{c}\right)\right]^{\frac{1-\beta_{c}}{\beta_{c}}}$ based on Equation (6).

There are three issues regarding the direct use of the residual $\varepsilon_{c}$ as a customer efficiency measure. First, this residual applies only to a specific channel. Greater precision can be potentially gained in estimation by aggregating estimates of this measure from observations across multiple channels, especially if there is some random variation in the residual due to unrelated factors. Second, other unobservable customer-specific effects might affect customer channel choice. Thus, the observed residual can include a term (s) which can be a customerspecific fixed or random effect: $\varepsilon_{c}^{\prime}=\frac{\beta_{c}}{1-\beta_{c}} \log A_{c}+s$. Third, the production function in Equation (2) applies to both self-service and employee service channels due to the inherent co-production nature of each service delivery process (Chase 1978), though the level and extent of a customer's participation can vary substantially. Our expectation and much of the prior literature suggests that the amount of customer labor input in full-service channels is smaller than that in selfservice channels, for a given transaction type (see e.g., Xue and Harker 2002). This implies a low elasticity of labor input $(\beta \approx 0)$ in full-service channels, and therefore minimal variation in channel use due to the direct effect of efficiency $\left(A^{\beta} \approx 1\right)$. However, the full-service channel use may be helpful in estimating individual effects (s), so they can be usefully incorporated into a composite efficiency measure.

Therefore, to minimize the effect of random variation and eliminate the customer-specific effects, we construct an overall efficiency measure as a weighted difference between the residuals in full service (C') versus self-service (C') channels: 


$$
C E=\sum_{c \in C^{\prime}} \theta_{c} \varepsilon_{c}-\sum_{c \in C^{\prime \prime}} \theta_{c} \varepsilon_{c}
$$

where $\sum_{c \in C^{\prime}} \theta_{c}=\sum_{c \in C^{\prime \prime}} \theta_{c}$ in order to eliminate $s$. The optimal weights are theoretically related to the variance of each residual and are proportional to the marginal product of labor in each type of channel (through $\frac{\beta_{c}}{1-\beta_{c}}$ ). To control for variance in the residuals, we standardize them to a mean of zero and a standard deviation of 1 . We then assign weights of the residuals of different channels. There are a variety of ways of weight assigning depending on the focus of the study and the empirical setting. Our preferred approach is to include weights proportional to the monthly transaction counts in each channel for each customer because this weighting captures a sense of individual customer's relative effort across channels over time. Alternatively, weights can be done with the population average channel use or equal weighting. We empirically investigate these alternative weightings and find their use does not alter our major conclusions, so we focus on our preferred measure in most of our analysis (see Section 4.3 for more details).

\subsection{Empirical Implementation}

Our prior derivation suggests that variation in transaction use across channels depends on a series of customer factors including cost of labor, customer capital, and relative customer value of the service. In addition, there are firm factors that can affect customer channel choice. Some firm choices have effects that can vary by customer, such as the location of branches and ATMs relative to each customer's home or place of work, while others affect all customers equally (the design of the Internet banking interface). Finally, there will be variance in channel use due to customer efficiency, some of which is due to observable factors and some of which is not directly or indirectly observable. Our principal empirical task is to construct suitable proxies for each so that we can: a) isolate customer efficiency from other factors that affect channel choice and b) provide support to the claim that our definition of customer efficiency is measuring what we expect by demonstrating that it is correlated with factors we believe to be associated with efficiency (e.g., education) in a plausible way. Below we describe the variables used in our empirical study to capture the factors that are influential on customer channel use in retail banking: 
Factors that affect customer efficiency. A large body of literature in labor economics has emphasized that skill, training and experience can affect labor productivity both generally as well as in technology-mediated self-service (Bartel and Lichtenberg 1987, Bartel 1995, Ichniowski et al. 1997; Gurau 2002, Wang et al. 2003). We capture training as the level of education in the household, because it is plausible that general human capital is associated with efficient transaction behavior, especially in the Internet channel. We capture experience by a customer's tenure. Tenure (measured in years) represents a measure of familiarity with the bank and might be plausibly related to productivity improvements through learning by doing. We can also compute the time since adoption of online banking, which provides an alternative learning-bydoing measure specific to the online banking channel. This measure may also be associated with computer skill, because early adopters are likely to be more skilled with computers. Finally, we are fortunate to have an additional potential proxy for computer skill - a market research indicator of whether the customer shows an "interest in computers" which might be associated directly with computer skill. We would therefore expect that use of self-service channels and customer efficiency are positively related to education, tenure, and computer experience and interest. We also have a measure of customer age. Greater age and experience might be associated with greater efficiency from learning-by doing argument. However, older customers may differ from younger customers in that they have less experience or comfort level with technology-mediated self-service channels (see e.g., Hitt and Frei 2002, Bitner et al. 2000, Curran et al. 2003, Gurau 2002, Wang et al. 2003). Since our age measure varies only in the cross-section, customer heterogeneity likely dominates the learning effect and we would therefore expect a negative correlation between the self-service usage and customer age. Finally, several of the time-dependent variables, such as age and tenure, may be associated with lifecycle effects that lead to a non-linear relationship with efficiency. We therefore allow for these effects by including quadratic terms in the empirical analysis for these variables.

Opportunity Cost. A number of studies have suggested that income is a good proxy for the opportunity cost of time (Becker 1993). We therefore approximate the unit labor cost (w) by annual household income of the customer. 
Transaction Value. We control for the number of transactions of each type that can be conducted in a channel as a way of normalizing the transaction counts based on the customer's overall transaction requirements. This measure is also consistent with treating total transaction counts of each type as exogenous. These variables may also broadly capture variation in customers' value of transactions $(v)$ because value affects the total number of transactions of a given type but not their allocation across channels.

In addition to potentially capturing transaction value, there is an additional benefit to incorporating measures of transaction mix into the analysis. A number of prior studies have shown that the nature of the product and transaction has a strong relationship with the optimal use of technology mediation for service delivery (Huete and Roth 1988), which would suggest that more standardized transactions would be likely to be done in self-service channels that have a high technology mediation level (Boyer et al. 2002, Froehle and Roth 2004). By incorporating measures of transaction counts, we can empirically examine whether self-service channels are more closely associated with more routine transactions.

Channel Access. Classical facility and location theories in service operations management have long established that the ease of access to a physical outlet of a service provider is crucial to a customer's decision to choose a service provider (Boyer et al. 2002). The availability of a channel directly affects the usage of that channel because it lowers opportunity costs. Channel availability can also affect the demand for other channels for which they are substitutes (Boyer et al. 2002). Thus, customers located in areas with higher branch density may perform more branch transactions and less transactions in other channels; similarly, customers located in areas with more ATMs may perform more ATM transactions and less transactions in other channels. Customers located in areas where there is a high density of physical channels may use virtual channels less. Because these factors are really control variables in our analyses, we are principally interested in whether these variables perform as expected as a check on the model rather than as an explicit empirical hypothesis.

Channel Design. Channel design and product structure can influence channel choice. However, because we only observe the choices of a single bank over a relatively short time period, the 
variation in behavior due to channel design is likely to be small. Nonetheless, to control for variation over time in channel design or incentives, we incorporate monthly dummy variables. In addition, the institution we analyze operates across a number of different states with slightly different products and business practices. Due to banking regulations which are principally state-specific, products within a state tend to be similar. Thus, we also include dummy variables for the customer's state of residence to control for variation in channel design, products or other aspects of the service production process.

\subsection{Testable Hypotheses}

Our hypotheses focus on the measurement of customer efficiency and its relationship with firm performance. First, we can conduct analyses of individual channels to understand whether the factors associated with efficiency (which we will refer to as efficiency correlates) are correlated with channel use in the expected way. From our earlier discussion, efficiency correlates should be positively related to self-service use. Moreover, because self-service channels can substitute for other channels, more use of self-service may lead to less use of employee service channels. Thus, we posit that:

Hypothesis 1-1: Factors associated with customer efficiency (age, tenure, education, skill) are positively correlated with self-service channel use and negatively correlated with employeeservice channel use.

These hypotheses will be tested at a finer level of precision (e.g. correlation between age and use of teller transactions), but are stated broadly here for concise presentation. Our data also allows us to examine the relationship between transaction complexity and channel choice as suggested by the prior literature (Huete and Roth 1988, Boyer et al. 2002):

H1-2: Customers use self-service channels more often than employee-service channels to meet routine and standard service needs in a multi-channel service delivery system. 
Second, our interest is in creating a systematic measure of customer efficiency based on the aggregate channel utilization. Just as our efficiency correlates should show the proper correlation with each channel, they should show the appropriate correlation with our aggregate efficiency measures.

H2: Customer efficiency, as defined and measured in this analysis, is positively correlated with tenure, education, and computer skill, and negatively correlated with age.

Finally, we would like to test whether indeed customer efficiency is associated with firm performance. Although there are theoretical reasons to expect either a positive or negative correlation between performance and customer efficiency in banking, we state our hypothesis in terms of the positive prediction.

H3: Customer efficiency is positively correlated with customer profitability, product utilization and retention.

The hypothesized relationships among customer efficiency, channel use and firm performance are shown in Figure 2. 
Customer Factors

- Customer Efficiency (customer-view)

o Age

o Education

o Tenure

o Computer Skill

- Customer Time Opportunity Cost

- Transaction Value

- $\quad$ Service Requirements
Combined Factors (Firm and Customer)

- Channel Access
Firm Factors

- Channel Design

- $\quad$ Product Design (e.g., channel use incentives)

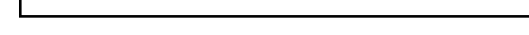

(1)

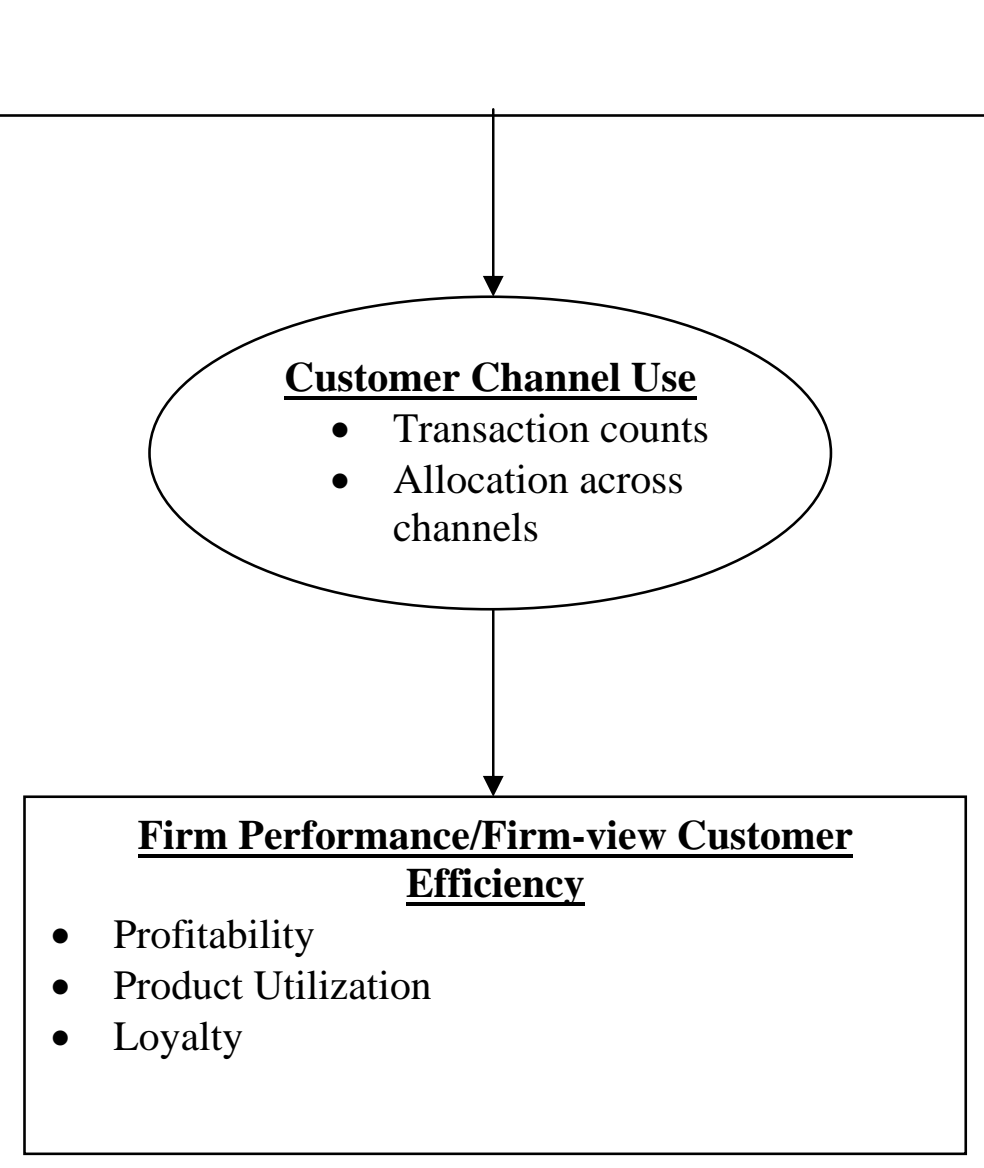

Figure 2: Hypothesized Relationships between Efficiency, Channel Usage and Firm Performance 


\section{Empirical Analysis}

Our empirical analysis includes three components. First, we will examine the determinants of channel utilization to validate our model of channel use on an individual channel level (to test H1-1 and H1-2). We will also examine the various control variables for consistency with prior theoretical predictions about channel access and channel usage. Next, we will compute several alternative measures of customer efficiency and test the hypothesis that customer efficiency is related to customer characteristics in a systematic way (H2). Finally, we will use our customer efficiency measure to investigate the relationship between efficiency and firm performance, specifically profitability, product utilization and retention (H3). All analyses were performed using standard procedures in STATA 8.0.

\subsection{Data}

The retail banking industry has been a pioneer in applying new technology to deliver services to its customers. Most retail banks today have built multi-channel service delivery systems similar to the one shown in Figure 1. These systems typically include retail branches (in which transactions are conducted in person by tellers and "platform" sales representatives), telephonebased customer service representatives (CSRs), automated Voice Response Units (VRUs), Automatic Teller Machines (ATMs), and Internet banking. In addition, customers can generate transactions by writing checks or by using the automated clearing house (ACH) for direct debit or credit of their accounts. Among these channels, teller, VRU, ATM, Internet and ACH are often used to handle standard and routine transaction types such as straightforward inquiry, deposit, withdrawal, and account transfers; CSR and platform are often used to handle more customized or complex service needs. Although we will analyze our model in all the channels for which we have data, we will focus our efficiency analysis on one full-service channel (tellers), and three self-service channels (VRUs, ATMs, and online banking) because these channels have the best measurement in our data and are not subject to issues such as serving non-standard transactions (platform) or being fully automated and not requiring any customer effort (ACH). 
The bank used in our study is one of the largest retail banks in the U.S., and its operational practices and customer population are regarded as representative of banks of similar size. From a raw data set of the bank's several million customers, a random sample of about 25,000 households was drawn and used for this study. We restricted our analysis to customers who appear in the banks customer information file and who had at least one transactional deposit account, since it does not make sense to analyze transaction behavior for customers who do not routinely perform transactions. These data include monthly transaction records for each customer's deposit accounts organized by transaction type and channel for each month from July 2002 to June 2003; monthly account balances for each deposit, loan and investment account for these customers over the same period. We define deposit accounts to include time deposits, interest and non-interest checking, and money market accounts. Loans include consumer loans, auto loans, credit cards and mortgages. Investment accounts include trust, asset management, brokerage accounts and mutual funds (with mutual funds being the most common). We also use the bank's bi-monthly profit measure which is based on an internal model that incorporates interest and non-interest revenue, less service costs (including overhead allocations), expected loan loss and taxes.

For each customer we have a single cross-section of demographic information which includes the date the customer first joined the bank, the date the customer obtained Internet banking access (if any), and standard demographics (age, income, education level, gender, marital status, presence of children, and zip code of principal residence). In addition, these data also include market data purchased from a third party which captured "interest in computers" (a binary measure). Finally, we obtained information on the bank's own ATM and branch networks, which provided a count of the number of branches and bank-owned ATMs in each zip code area.

The transactional and account data was obtained from the bank's transactional systems and therefore is believed to be of high quality. However, for some channels, notably platform and telephone CSRs, the bank does not track all transactions in its online systems, so we limit our analyses of these channels. The transaction file also omits non-inquiry VRU transactions, but these are believed to be a relatively small portion of overall VRU activity. The customer data (other than those derived from transactional data) are collected as part of the bank's normal 
operations and are supplemented by third-party market research data. These data are also believed to be highly accurate, although some data are missing. The data of ATM and branch locations are drawn from the bank's operational databases and are also believed to be extremely accurate and complete. As for the profitability data, although there is some subjectivity in the calculation of customer profitability, especially due to cost allocation procedures, these data are used for internal performance measures. Regardless of its potential flaws, customer profitability is one of the measures which the bank actively monitors and attempts to maximize.

All the data described above is at individual customer level, so we conduct our analysis at the customer level with each observation representing a household in a given month. Observations are not excluded for missing data on the demographic variables. Instead, we include a dummy variable to indicate if the data is missing and set the value to the variable mean for a continuous variable, or have an explicit “missing” category for all categorical variables. This procedure ensures that the results are not sensitive to the value used to fill missing data. A consequence of this data selection process is that our data includes a mix of new customers over our period, customers who stayed throughout the 12-month period, and customers who abandoned some or all of their accounts. Because the bank retains customer information data after customer departure, our counts of departure are not skewed by missing data on the characteristics of customers who departed. We also validated that our proportions of new, departing and continuing customers match the customer population.

We utilize three outcome measures in our performance analysis: customer profitability (as computed by the bank), product utilization, and customer retention. Product utilization is measured by the aggregate balance for each of the three types of accounts a customer holds: deposit, asset and investment accounts. Because the economics of these three account types are similar within category (e.g., interest and non-interest checking accounts are similar) but different across categories (e.g., mutual funds are different from loans), we perform separate analyses for each of these categories, but do not use broader aggregates. Customer retention is measured as a binary variable that captures whether a customer closed all her accounts. These measures are consistent with other research in banking performance at the customer level (e.g., 
Hitt and Frei, 2002), as well as with the performance metrics that the bank utilizes internally. Table 1 presents definitions and summary statistics of our key variables.

\subsection{Channel Use Analysis}

Using our service co-production model in Section 3, our general empirical model for channel demand relates the total number of transactions in a channel to correlates of customer efficiency (age, tenure, interest in computers, online banking tenure), correlates of cost of customer effort (household income), correlates of transaction value (total transactions by type), channel availability (branch density, ATM density, having online banking), and other control variables for customer characteristics (martial status, having children, gender) and variation in bank characteristics (month, customer state of residence). Time-related variables (age, online banking tenure, customer tenure) are both entered as linear and as squared terms to account for lifecycle effects and other non-linear trends. The variables for income and education are categorical and are expanded to a set of dummy variables, so no ordering is imposed on these measures. Thus, our baseline empirical model is:

$$
\begin{aligned}
& \log \left(1+T_{c}\right)=\beta_{0}+\sum_{j \in J} \delta_{j} \log \left(1+T_{j}\right)+\beta_{\text {age }} \text { age }+\beta_{\text {age }{ }^{2}} \text { age } e^{2}+\beta_{\text {comp }} \text { comp }+\beta_{\text {college }} \text { college }+\beta_{\text {graduate }} \text { graduate }+ \\
& +\beta_{\text {tenure }} \text { tenure }+\beta_{\text {tenure }} \text { tenure }{ }^{2}+\beta_{\text {eb-tenure }} e b-\text { tenure }+\beta_{\text {eb-tenure } e^{2}} \text { eb-tenure } e^{2}+\beta_{\text {atm }} \text { atm }+\beta_{\text {branch }} \text { branch } \\
& +\beta_{\text {has_eb }} \text { web }+\beta_{\text {med-income }} \text { med }- \text { income }+\beta_{\text {high-income }} \text { high }- \text { income }+\beta_{\text {gender }} \text { gender }+\beta_{\text {children }} \text { children } \\
& +\beta_{\text {married }} \text { married }+ \text { state_dummies }+ \text { time_dummies }+\varepsilon
\end{aligned}
$$

We estimate this equation using monthly data of each customer's transactions in each of five channels (teller, VRU, ATM and online banking, and ACH), although we exclude ACH from our efficiency measure later, because ACH is fully automated. Because transaction count variables (transactions in a given channel $T_{c}$ and transactions of a given type $T_{j}$ ) can be legitimately zero, we add one to the transaction count before taking the logarithm to prevent a zero observation from creating an extreme point. Transaction types that cannot be conducted in a particular channel (e.g., deposits in the VRU channel) are omitted from the regression. For the two sets of categorical variables for education and income, the "lowest" category is omitted (high school education, low income). Because the dependent variable is the logarithm of transactions, the 
coefficients (except for the transaction count controls, which are also in logarithms) can be interpreted as percentage changes (e.g., $\beta_{\text {college }}$ is the percentage difference in transactions between a college educated customer and a high school educated customer). For variables entered in both linear and quadratic terms (e.g., age), both coefficients need to be examined to determine the relationship. Where relevant, we will discuss both the trend (increasing or decreasing) and where the minimum/maximum point is achieved (for relationships that are convex or concave). For example, for age, this point is achieved at $\frac{-\beta_{\text {age }}}{2 \beta_{\text {age }}}$. In many cases, this will show that the minimum or maximum is at the edge of the data range, so the relationship is effectively monotonic over the sample range. For all channels except the online banking channel, the estimates will be performed using ordinary least squares with Huber-White robust standard errors (clustered by customer) to account for repeated customer observations over time (Wooldridge, 2002). These analyses are done with the STATA "reg” procedure.

For online banking, we have to account for the fact that some customers have not initiated online banking and therefore their online transaction count will be zero. There are two ways of handling this issue. One option is to restrict our analysis only to customers with online banking. However, this analysis can be biased by customer self-selection (Tobin 1958, Maddala 1983). Our preferred method is to treat the "desired" number of online banking transactions as a latent variable which is censored at zero. This formulation leads to the use of a generalized Tobit model (the interval regression model) that allows both censored observations of customers without Internet accounts and non-censored observations of customers with Internet accounts (Tobin, 1958, Goldberger 1964, Maddala 1983, Long 1997). This model was estimated using the STATA “intreg” procedure. The results of these analyses are presented in Table 2, with each column representing an analysis of an individual channel.

In our testing of hypothesis H1-2 and some other discussions later, we refer to coefficient comparisons across models for different channels. For these comparisons, we compute statistical significance by noting that coefficients in two different regressions are statistically independent, so the standard error of the difference can be computed by the simple formula for the variance of a difference of two independent random variables. Because the sample size is the same for all 
our channel use regressions, the appropriate test for the equality of two hypothetical coefficients $\beta_{1}$ and $\beta_{2}$ with regression standard errors $S E\left(\beta_{1}\right)$ and $S E\left(\beta_{2}\right)$ is a t-test given by: $t=\frac{\beta_{1}-\beta_{2}}{\sqrt{\frac{1}{2}\left[S E\left(\beta_{1}\right)\right]^{2}+\frac{1}{2}\left[S E\left(\beta_{2}\right)\right]^{2}}} \cdot$

Overall, the models are all significant $(\mathrm{p}<.001)$ and the results (see Table 2$)$ in this analysis are broadly supportive of the hypothesized relationships among self-service usage and correlates of customer efficiency (H1-1) and the relationship between self-service usage and transaction type (H1-2).

Age. Customer age is generally positively associated with full-service transactions (tellers) ( $\left.\beta_{\text {age }}^{\text {teller }}=.021, p<.01\right)$ and age has a negative and significant correlation with the use of selfservice channels which is strongest for online banking $\left(\beta_{\text {age }}^{\text {ebanking }}=-.026, p<.01\right)$. The quadratic terms are also significant but small, generally suggesting that the relationship between transaction use and age is monotonic over the sample (the maximum is reached at $-\frac{.0205}{2(-.00016)}=64.1$ years for tellers and the minimum is reached at age 60 years for online banking, which are both around the $90^{\text {th }}$ percentile of the sample age distribution).

Experience/Tenure. The tenure results are mixed. For the most part, greater relationship length with the bank is associated with less usage of two self-service channels (ATM and online banking) as well as less usage of tellers. There are positive relationships with VRU usage and $\mathrm{ACH}$. Examining the quadratic terms suggests that these trends persist over the entire sample distribution or at least far out in the upper tail (the earliest minimum is reached in the teller channel at a tenure of 16.4 years, which is close to the $90 \%$ percentile of the tenure distribution). We therefore conclude that this analysis does not show any systematic relationship between length of relationship and choice of channel.

Experience/Online Banking Tenure. The results are closer to expectation on online banking tenure. An additional year of experience in online banking is associated with a $5 \%$ decrease in 
the number of teller transactions (significant at $\mathrm{p}<.01$ ) and this holds across the entire sample. The relationship between online banking tenure and the use of other channels is more complex. Initially, the number of online banking transactions is declining in online tenure, reaches a minimum at approximately 1.9 years and is increasing thereafter. VRU use initially increases following the adoption of online banking but decreases as online banking tenure moves beyond the mean. The initial increase in VRU use may be consistent with the increased demand on telephone support for Internet customers learning to use the system (this interpretation was suggested by managers we interviewed as part of this research). The same holds for ATMs, but the decreasing region is reached much faster (.65 years) suggesting a negative relationship with online banking tenure. ACH use is increasing in online banking tenure, although this may be partially expected for technical reasons - automatic bill pay in the online banking channel is often fulfilled through the ACH system. Overall, the declining use of teller transactions and the increase use of the online channel for long-time users suggests channel substitution, which is fully consistent with H1-1. In addition, the convex relationship between online banking use and online banking tenure suggests that it takes a period of time before online banking is fully utilized, and at that time it becomes a substitute for other self-service (VRU and ATM) and fullservice channels (teller).

Education. The hypothesized relationships also hold generally for self-service channel usage and education. Point estimates suggest that the highest levels of education are consistently associated with greater use of self-service channels and less use of full-service channels except for VRUs. Customers with a graduate degree perform 12\% fewer teller and nearly 15\% more ATM transactions than do customers with a high school education (these differences are significant at $\mathrm{p}<.01$ ). The results of online banking are mixed - college educated customers actually perform fewer online banking transactions than high school educated customers while customers with a graduate degree perform higher numbers of transactions than either group, but none of the results are significant. The one unusual finding is that VRU use is declining in education. This may, in part, be due to the fact that the VRU is a gateway to telephone CSRs, which makes the VRU channel have some of the appearance of a full-service channel as well (that is, calls to the CSR are first routed through the VRU, with an option to "speak to a customer representative”). For this reason, we omit the VRU channel from our subsequent efficiency 
analysis since our measure of VRU transactions may confound self-service transactions with attempted full service transactions through CSRs.

Skill/Interest in Computers. Generally, the coefficients on "interest in computers" are in the right direction but tend to be small and insignificant for most channels. Expressed interest in computers is associated with 9.3\% greater online banking transactions, but even this number is not significant at conventional levels $(t=1.5)$. Thus, the results on this variable are inconclusive but not inconsistent with our hypotheses. The lack of power of this variable may simply be due to imperfect measurement, an issue which can hopefully be addressed in future research.

Channel Availability. There is a clear relationship between customer adoption of online banking and lower numbers of transactions in all other channels except $\mathrm{ACH}$, which shows a modest increase. The greatest relationships are the VRU channel (38\% less use for customers with online banking after controlling for tenure) because the capabilities between online banking and the VRU are similar. Similarly, customers with online banking access perform nearly $13 \%$ fewer teller transactions. As observed in the online banking tenure analysis, ACH appears to be a complement to online banking. The results are not as strong for other channel availability measures but are largely consistent with our hypotheses. Greater numbers of available ATMs in the customer's home zip code area is associated with fewer teller transactions and more ATM transactions, suggesting that ATMs are substitutes for tellers, as would be expected. One additional ATM is associated with a $0.8 \%$ decline in teller transactions and a $2 \%$ increase in ATM transactions. ATMs appear to be substitutes for the other channels, although these coefficients are not significant. The results of branch density are puzzling. More branches are associated with less branch transactions and more use of online banking. Although this is inconsistent with our story of branch availability, it could indicate that branches tend to have the highest densities in communities that also have a propensity to use online banking such as urban settings. Thus, it appears that it may be acting as a control for unobserved demographic factors. Unfortunately we are not able to test this further because the branch data and our geographic control are both at the same level of aggregation (zip code), which means we cannot use a zip code control to eliminate this source of variation. 
Opportunity Cost. The results on income are consistent with an argument that customers may utilize self-service to economize on opportunity costs. Medium-income consumers perform nearly $13 \%$ more online banking transactions and 3\% more ACH transactions. The relationship is even more pronounced for high-income customers: high-income customers conduct $28 \%$ more online banking transactions, 7\% fewer VRU transactions and 2\% fewer teller transactions (although the figure for tellers is only marginally significant at $\mathrm{p}<.1$ ). Interestingly, although income might be proxy for other factors such as education or computer skill, the fact that these numbers are substantial after controlling for both education and "interest in computers" provides greater confidence in our interpretation.

Transaction Volume. The results also support hypothesis H1-2, that simple transactions are more often accomplished in self-service channels. The coefficients suggest that a $10 \%$ greater number of inquiry transactions is associated with an approximately $1.8 \%$ increase in online banking transactions and a $1.3 \%$ increase in ATM transactions, but only a $0.5 \%$ increase in teller transactions. In other words, the results are consistent with the argument that a marginal inquiry transaction is more likely to be directed to a self-service channel. These differences between the coefficients on inquiries for the teller channel versus the other channels are all significant at $\mathrm{p}<.001$.

Other Controls. The control variables for state of residence and month are jointly significant and in most cases individually significant in all analyses. The same is also true for the family structure variables. Our theory does not provide specific predictions for these variables, so we cannot interpret them further in terms of our model. However, one interesting observation is that households where women are the primary account holder are significantly more likely to perform transactions in the online channel and less likely to use tellers, an observation that might prove useful in marketing efforts for online banking.

\subsection{Customer Efficiency}

Using the approach described in Section 3, we now construct measures of customer efficiency. We first perform regressions of channel usage against all covariates in our model except those 
associated with customer efficiency. The standardized residuals from this regression are used to construct four efficiency measures as described in Section 3. CE1 is computed as the difference between the two self-service channel residuals (ATM, online banking) weighted by number of transactions an individual customer performs in each channel each month, and the residual of the teller channel. CE1 is our preferred measure as it accommodates transaction differences across consumers over time and does not include the potentially problematic VRU channel. For the purpose of robustness check we also construct alternative measures. CE2 is the same as CE1 except that it includes VRU as a self-service channel. We also computed two additional measures, also omitting the VRU channel: CE3 uses weights proportional to population means rather than customer specific time-varying weights, and CE4 utilizes equal weights. In all cases, the efficiency measures are standardized to a mean of zero and a standard deviation of 1 to ease interpretation. These measures are then regressed on the customer efficiency covariates using ordinary least squares with Huber-White robust standard errors (Wooldridge 2002) using the STATA “reg” procedure. (see Table3).

Overall, the models are all significant $(\mathrm{p}<.001)$ and the results on the efficiency measures mirror our earlier analysis (Table 3) and lends support to hypothesis H2. Age is negatively related to efficiency, which is significant for CE2, CE3 and CE4 although not significant for CE1. Efficiency is shown to be increasing in education, which is significant for the highest education level "graduate" for CE1 ( $\beta_{\text {educ-graduate }}^{\text {CE1 }}=0.13, p<.01$ ) and significant for both "college" and "graduate" for CE3 and CE4. The efficiency measures are all shown to have a concave relationship with tenure: for CE1 with the maximum roughly in the middle of the sample (9 years) - thus, efficiency is initially increasing in tenure, then decreasing. This is similar to the results for the individual channel analyses. Efficiency is increasing in experience with online banking up to the midpoint of the sample (the maximum is achieved at 1.6 years) and then declining in tenure although tenure has a net positive contribution over the entire sample range. Thus, efficiency is broadly related to age, education, online banking tenure and overall customer tenure though the results on "interest in computers" are inconclusive.

Overall, examining the columns of Table 3, it appears that although there are some variations in the results from the different efficiency measures they are broadly consistent, which suggests the 
empirical performance of our efficiency measure is not particularly sensitive to the choice among plausible weight schemes.

\subsection{Customer Efficiency and Performance}

We consider three measures of performance: profitability as computed by the bank, product utilization, and retention. The baseline model relates the dependent performance variable (designated generically by $P$ ) to customer efficiency (and its square to account for nonlinear effects), and to a set of control variables suggested by our channel use model. We include customer efficiency correlates in addition to customer efficiency for two reasons: first, it may improve empirical performance of the model if these variables have a direct relationship with performance; second, our results are more conservative and perhaps more relevant because the efficiency measure now can be interpreted as efficiency that was not otherwise observable through the efficiency correlates. Thus,

$P=\beta_{0}+\beta_{C E} C E+\beta_{C E^{2}} C E^{2}+\beta_{\text {age }}$ age $+\beta_{\text {age }^{2}} a g e^{2}+\beta_{\text {comp }}$ comp $+\beta_{\text {college }}$ college

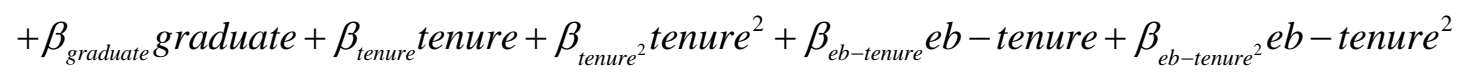

$+\beta_{\text {atm }}$ atm $+\beta_{\text {branch }}$ branch $+\beta_{\text {has_eb }}$ web $+\beta_{\text {med-income }}$ med -income $+\beta_{\text {high-income }}$ high-income

$+\beta_{\text {gender }}$ gender $+\beta_{\text {children }}$ children $+\beta_{\text {married }}$ married + state $\_$dummies + time $\_$dummies $+\varepsilon$

We also examined variations of the model which include transaction count controls (the counts of different types of transactions of the customer) and channel count controls (the counts for transactions in various channels of the customer).

We utilize Huber-White robust standard errors to correct for repeated observations of the same customer over time (Wooldridge 2002) except in fixed-effects and random-effects analyses which already control for repeated observations. For the profitability analysis, the dependent variable is the bank's internal profit measure. For product utilization, we utilize the logarithm of account balance as the dependent variable for each type of product (deposit, assets and investment). All of these models are estimated by ordinary least squares (using the STATA “reg” procedure) as well as by fixed and random effects panel data models (using the STATA "xtreg” procedure). For the retention analysis, we utilize logistic regression where the dependent variable (depart) is set to one if the customer departed the bank and zero otherwise (using the 
STATA "logit" procedure). Overall the models are all significant $(\mathrm{p}<.001)$ although some have a relatively small R-squared (see further discussion below) and the results are generally supportive to hypothesis $\mathrm{H} 3$.

Profitability. The profit results are shown in Table 4. The baseline model (Column 1) suggests that more efficient customers are more profitable - a customer that is one standard deviation above the mean in efficiency contributes $\$ 4.76$ of additional monthly profit $\left(\beta_{C E 1}^{\text {profit }}(1)+\beta_{C E 1-\text { squared }}^{\text {profi }}(1)=4.76, p<.01\right)$. This relationship continues to hold (and is significant) when we control for transaction types (Column 2) and actually gets stronger when we utilize a fixed effects analysis that controls for all time-invariant customer characteristics (Column 4). Results of a random effects panel data model are similar (not shown).

In addition, the estimates of the model with channel controls (Column 3) suggest that the allocation of transactions across channels does explain the relationship between efficiency and profitability. When controls for channel usage are included the coefficients are large and negative (as channel use incurs cost), and the efficiency coefficient turns slightly negative. This suggests that more efficient customers are associated with greater profits principally due to allocation of transaction activity across channels, not because of a change in the overall mix of actual transaction types (consistent with our treatment of these as exogenous), nor due to incremental revenue enhancing behaviors. If customer efficiency had no relationship with profits except through channel transaction volume, this CE1 coefficient should be close to zero. We will consider the possibility of revenue differences further in the product usage analysis.

The control variables in these regressions also appear to be reasonable. Profitability is increasing in income, as would be expected. Interestingly, although ATM density is largely unrelated to profitability, branch density is associated with higher profitability. This is consistent with our explanation of a prior result that branch density was associated with higher online banking adoption. It may be that branch density acts partially as a proxy for unobserved demographic variables in addition to representing the availability of the teller and platform channels. The overall fit of the regression is somewhat small with an $\mathrm{R}^{2}$ of around $2 \%$. This is not surprising as customer profitability in retail banking is known to vary considerably across customers (see e.g., 
Hitt and Frei 2002) for idiosyncratic reasons. However, due to our large sample size, most of the variables are significant individually and jointly. Overall, these results lend support for $\mathrm{H3}$.

Attrition. The attrition results shown in (Table 5) suggest a convex relationship between attrition rate (the probability of departing the bank) and customer efficiency. Column 1 shows the linear CE1 coefficient to be negative and the quadratic term coefficient to be positive (both significant at $\mathrm{p}<.01$ ). A customer with a very low efficiency has a higher attrition rate that is reduced as efficiency increases. This negative relationship between efficiency and attrition persists until attrition is minimized at .96 standard deviations above the mean of CE1, and is increasing with efficiency thereafter. The result is similar, although weaker with transaction type controls (Column 2). In Column 3 we add channel usage controls. Greater use of tellers and the online banking channel are both associated with less attrition, although the teller relationship $\left(\beta_{\ln t}^{\text {depart }}=-.22, p<.01\right)$ is more than double the coefficient on online banking $\left(\beta_{\ln e b}^{\text {depart }}=-.12, p<.01\right)$. This suggests that while more use of self-service is associated with decreased departure, the relationship is much stronger with the full service teller channel. However, unlike in the profitability analysis, the relationship between attrition and efficiency (with channel use controls) becomes much stronger and suggests a negative relationship between attrition and efficiency over almost the entire sample (the departure rate is minimized at 3.7 standard deviations above the sample mean which is above $99 \%$ percentile of the sample distribution). Thus, while the general relationship between efficiency and departure is negative, the very lowest and highest efficiency customers show greater attrition. Since we believe the results without channel usage controls are the proper way to interpret CE, this provides mixed support for $\mathrm{H} 3$.

Product Utilization. The results on product utilization are similar in direction to the results on attrition. In Table 6, we estimate separate regressions for each of the three account types: liabilities (deposit accounts), asset accounts (loans), and investment products (principally mutual funds). Each regression was performed using OLS, random effects (not shown but similar to OLS), and fixed effects models. The results consistently show a concave relationship between product use and efficiency where balances are maximized around or above the sample mean. In OLS, deposit balances are maximized at .84 standard deviations above the sample mean of 
efficiency. Similar results hold for asset balances (concave with maximum at 0.2 standard deviations) and investment balances (concave with maximum at -.02 standard deviations relative to the mean). The results of the fixed effects analyses are more consistent - all show concave relationships with significant linear and quadratic terms and that balances are maximized in the range of 1.4 to 1.9 standard deviations above the mean (about the $90^{\text {th }}$ percentile of the sample distribution). Thus, the balances results also provide partial results for $\mathrm{H} 3$, although the relationship between customer efficiency and product utilization is more complex (being curvilinear rather than linear) than we had anticipated.

The control variables in these analyses are mostly insignificant and generally mixed in sign. Education is consistently positively associated with balances but often not significant. One notable exception is income, which as expected has a large and positive relationship with balances - a high income customer has approximately $87 \%$ higher liability balances, 68\% greater asset balances and 37\% percent greater investment balances than a low income customer. These coefficients as well as the coefficients on medium income are all significant at $\mathrm{p}<.01$.

\section{Summary and Discussion}

Operations managers across service industries face the challenge of designing and managing an increasingly complex multi-channel service delivery system that consists of both traditional, physical, employee-provided service channels as well as virtual, self-service channels. Given the co-production nature of service production, a crucial step toward successful service design and management is to understand both how customers utilize these channels and the corresponding impact on firm performance in short and long term. This requires identifying a wide array of factors that affects customers' channel choices. Prior literature has developed the theoretical argument that customer efficiency, defined as a customer's efficiency of participation in the service co-production process, should be associated with greater self-service utilization, and that greater customer efficiency is therefore associated with greater firm performance. In addition, many of the customer characteristics that should be associated with greater customer efficiency have been previously identified. We make two specific contributions to this literature. First, we develop an approach for the measurement of customer efficiency utilizing channel demand, 
enabling examination of customer efficiency issues without requiring complete data on all customer inputs and outputs. Instead, we measure efficiency as a residual in a model of selfservice channel use after controlling for channel availability and other factors unrelated to efficiency. Analysis using this measure suggests that our efficiency measure is correlated with many demographic characteristics in the expected way. Second, we utilize our efficiency measure to examine the relationship between customer efficiency and performance, a relationship which has been hypothesized but rarely tested. Our results suggest that customer efficiency is strongly and positively associated with customer profitability across the sample. We also find that customer retention and product balances are increasing in efficiency for at least half the sample which is consistent with expectations, but that the very highest efficiency customers have lower retention and lower balances than other customers which was not anticipated by our model and theoretical discussion. We also find support for theories presented in prior work in service operations, that self-service channels that often have high automation levels are relatively favored by bank customers for simple and standard transactions in comparison to employee service channels.

While our efficiency measure has practical advantages, it also has some theoretical disadvantages shared with other approaches that capture a latent construct as a residual (for example, the Solow residual of multifactor productivity - see e.g., Solow 1957 -- also has this disadvantage). In particular, we rely heavily on prior assumptions and model specification to establish that our residual measure indeed captures efficiency and not some other latent construct. As noted by Edwards and Bargozzi (Edwards and Bagozzi 2000) the elimination of unwanted causal factors from empirical measures is well known but difficult problem for empirical testing of social science constructs. We attempt to minimize this problem by using theoretically motivated control variables and checking the results of our analyses for consistency with prior theoretical and empirical arguments. Nonetheless, the ideal test would be to combine the direct measurement of customer inputs and outputs with our indirect measurement approach to see how much of our measure is due to efficiency as opposed to general customer heterogeneity. We hope to pursue this in future work. 
Our empirical analysis of transaction behavior uncovered two unexpected relationships. First, greater branch density is associated with fewer teller transactions and more online banking. This may be a causality issue because the factors associated with greater online banking usage are also likely to be associated with the areas with desirable demographics where branches might be constructed for non-transactional reasons (e.g., selling investment products, opening new accounts). However, since this variable is utilized as a control it does not lead us to question our core findings about customer behavior and efficiency. Second, we did not anticipate a strong concave relationship between product utilization and efficiency. Part of this observation is consistent with the idea that more efficient customers are better at managing their money which leads to lower balances. It may also be consistent with the idea that customers for whom transactional access is costly will tend to use fewer products. Regardless of the explanation, it is clear that the highest efficiency customers, by our measures, behave differently than other customers and further investigation into this issue is needed. The attrition results are easier to explain as there is a tension between online channel usage and increased retention and an even stronger relationship between retention and teller usage. Without knowing the causal direction of this relationship, whether loyal customers use online banking and tellers more or whether these channels build lock-in and encourage loyalty, it is difficult to understand whether interventions to alter channel utilization are likely to improve retention. It does, however, suggest, that efficiency and performance are related. It may be possible to disentangle these effects with a longer time series, which represents another opportunity for future research.

There are four additional limitations of the current study that suggest avenues for future research. First, our data is from a single bank. Given the random sampling approach and the sheer size of the bank we consider, our results are likely to be broadly representative of a large population. However, we cannot investigate the possibility that the customer choices we observe are affected by specific practices of this bank, such as account features (e.g., fee structure), channel characteristics (e.g., online banking system design or call center hold times), and brand positioning. We hope to expand the scope of the data collection in future research. In addition, although our model was motivated by our discussions with retail banking executives, it appears the model should apply to multi-channel service delivery systems in other industries as well. A study in a different industry would help to validate our customer efficiency measurement 
approach. Second, our customer transaction records only cover transactions for traditional deposit products. Because this represents the vast majority of discretionary retail banking transactions, this seems a reasonable starting point. However, as banks are increasingly reliant on non-traditional products (investment, brokerage, insurance) and these products are increasingly served through the same service delivery infrastructure, it would be useful to extend our analysis to consider these products beyond simply examining product utilization. Third, the explained variance in some of our performance regressions is relatively small, although all the models are highly significant. While we would generally prefer greater explanatory power, this most likely suggests that profitability and other performance dimensions are driven heavily by unobserved differences across customers. However, we do note that the significance levels of our efficiency measure are on the same order as factors known to be important in banking profitability, such as household income or transaction volume. Thus, explanatory power is a broader concern regarding the empirical setting, rather than a concern specific to our approach. This also suggests it would be beneficial to identify other constructs that can be used to further distinguish customer profitability differences among customers. Moreover, it also suggests that without substantial improvements in modeling or data on profitability, large sample sizes will be required for this type of research. Fourth, and finally, because we measure efficiency as a latent construct revealed through channel choice, we cannot directly investigate the relationship between efficiency and self-service usage. Our prior arguments suggest that at least some components of efficiency may be immeasurable, but it would be useful to compare our measure of customer efficiency to direct measures of customer behavior (e.g., time spent performing transactions) for the purpose of examining the accuracy of the measure and to understand the importance of unobservable components to overall customer efficiency. This issue exactly mirrors the concern in the firm productivity literature that focuses on methods for "explaining" multifactor productivity of firms given that it is also measured as a residual concept.

\section{Acknowledgements}

This study is supported by National Science Foundation (NSF) grants: SES-0518931 and SES0519054. The authors thank Aleda V. Roth, the senior editor and two anonymous referees for their constructive and valuable comments. 


\section{References}

Apte, U. M., A. P. J. Vepsalainen. 1993. High tech or high touch? Efficient channel designs for delivering financial services. Journal of Strategic Information Systems 2 (1) 39-54.

The Banker. 2003. Tuning into the right channels. 02 December 2003, 116.

Bartel, A., P. R. Lichtenberg. 1987. The comparative advantage of educated workers in implementing new technology. Review of Economics and Statistics, 64 1-11.

Bartel, A. 1995. Training, wage growth, and job performance: evidence from a company database. Journal of Labor Economics. 13 (3) 401-425.

Bateson, J. E. G. 1985. Self-service consumer: an exploratory study. Journal of Retailing 61 (3) 4976.

Becker, G. S. 1993. Human capital: a theoretical and empirical analysis, University of Chicago Press, Chicago, IL.

Bitner, M. J., S. W. Brown, M.L. Meuter. 2000. Technology infusion in service encounters. Journal of the Academy of Marketing Science. 28 (1) 138-149.

Bitner, M.J., W.T. Faranda, A.R. Hubbert, V.A. Zeithaml. 1997. Customer contributions and roles in service delivery. International Journal of Service Industry Management, 8(3) 193-205.

Boyer, K.K., R. Hallowell, A.V. Roth. 2002. E-services: operating strategy -- a case study and a method for analyzing operational benefits. Journal of Operations Management. 20 175-188.

Bowen, D.E. 1986. Managing customers as human resources in service organizations. Human Resource Management 25 (3) 371-383.

Chase, R. B. 1978. Where does the customer fit in a service operation? Harvard Business Review 56(6) 137-142.

Chase, R. B. 1981. The customer contact approach to services: theoretical bases and practical extensions. Operations Research 29 (4) 698-706.

Chen, P.Y., L. M. Hitt. 2002. Measuring switching costs and their determinants in internet enabled businesses: a study of the online brokerage industry. Information Systems Research 13(3) 255-276.

Choi, D., U. S. Karmarkar, H. Rhim. 2005. Service technology, access, and process economics in retail banking competition. Working paper, the Anderson School of Management, UCLA.

Curran, J. M., M. L. Meuter, C. F. Surprenant. 2003. Intentions to use self-service technologies: a confluence of multiple attitudes. Journal of Service Research. 5 (3) 209-224. 
Davis, T. 1993. Effective supply chain management. MIT Sloan Management Review 34 (4) 35-46.

The Economist. 2004. You're hired. 372 (8393) 21.

Edwards, J. R., R. P. Bagozzi. 2000. On the nature and direction of relationships between constructs and measures. Psychological Methods. 5 (2) 155-174.

Ellram, L.M., W. L. Tate, C. Billington. 2004. Understanding and managing the service supply chain, Journal of Supply Chain Management. 40 (4) 17-33.

Froehle, C. M., A. V. Roth. 2004. New measurement scales for evaluating perceptions of the technology-mediated customer service experience. Journal of Operations Management 22 1-21.

Fuchs, V. 1968. The service economy. Columbia University Press, New York, NY, U.S.A.

Globerson, S., M. Maggard. 1991. A conceptual model of self-service. International Journal of Operations and Production Management 11 (4) 33-44.

Goldberger, A.S. 1964. Econometric theory. John Wiley Publisher, New York, NY.

Griliches, Z. 1994. Productivity, R\&D and the data constraint. American Economic Review 84 (1) $1-23$.

Gurau, C. 2002. E-banking in transition economics: the case of Romania. Journal of Financial Services Marketing 6 (4) 362-378.

Heskett, J.L., W.E. Sasser Jr., L. A. Schlesinger. 1997. The Service Profit Chain: How leading companies link profit and growth to loyalty, satisfaction, and value. Free Press, New York, NY.

Hitt L.M., F.X. Frei. 2002. Do better customers utilize electronic distribution channels? The case of PC banking. Management Science 48 (6) 732-748.

Huete L., A. V. Roth. 1988. The industrialization and span of retail banks' delivery systems. International Journal of Operations Management. 8 (3) 46-66.

Ichniowski, C., K. Shaw, G. Prennushi. 1997. The effects of human resource management practices on productivity. The American Economic Review. 87 (3) 291-313.

Karmarkar, U., R. Pitbladdo. 1995. Service markets and competition. Journal of Operations Management 12 (3-4) 397-411.

Kelley, S.W., J.H. Donnelly, Jr. and S.K. Skinner. 1990. Customer participation in service production and delivery. Journal of Retailing 66 (3) 315-335.

Kellogg, D. L., R. B. Chase. 1995. Constructing an empirically derived measure for customer contact. Management Science 41 (11) 1734-1749. 
Long, J. S. 1997. Regression models for categorical and limited dependent variables. SAGE Publications, Thousand Oaks, CA.

Lovelock, C.H., R.F. Young. 1979. Look to consumers to increase productivity. Harvard Business Review 57 168-178.

Maddala, G.S. 1983. Limited-dependent and qualitative variables in econometrics. Econometric Society Monographs in Quantitative Economics. Cambridge University Press.

Menor, L. J., A. V. Roth, C. H. Mason. 2001. Agility in retail banking: a numerical taxonomy of strategic service groups. Manufacturing and Service Operations Management. 3 (4) 273-292.

Mills, P.K., J.H. Morris. 1986. Clients as "partial" employees of service organizations: role development in client participation. Academy of Management Review 11 (4) 726-735.

Roth, A. V. 2001. Siete mitos de los servicios electronics (Seven myths of electronic services). Harvard Business Review. 100 88-96.

Roth, A. V., L. J. Menor. 2003. Insights into service operations management: a research agenda. Production and Operations Management 12 (2) 145-163.

Roth, A. V., W. E. Jackson III. 1995. Strategic determinants of service quality and performance: evidence from the banking industry. Management Science 41 (11) 1720 -1733.

Soteriou, A.C., R.B. Chase. 1998. Linking the customer contact model to service quality. Journal of Operations Management 16 495-508.

Selnes, F., H. Hansen. 2001. The potential hazard of self-service in developing customer loyalty. Journal of Service Research 4(2) 79-90.

Solow, R. M. 1957. Technical change and the aggregate production function. Review of Economics and Statistics. 39 (3) 312-320.

Tobin, J. 1958. Estimation of relationships for limited dependent variables. Econometrica. 26 24-36.

Voss, C. 2000. Developing an eService strategy. Business Strategy Review 11 (1) 21-33.

Wang, Y., Y. Wang, H. Ling, T. Tang. 2003. Determinants of user acceptance of Internet banking: an empirical study. International Journal of Service Industry Management. 14 (5) 501-519.

Wooldridge, J. M. 2002. Econometric analysis of cross section and panel data. MIT Press, Cambridge, MA.

Xue, M., P.T. Harker. 2002. Customer efficiency: concept and its impact on e-business management. Journal of Service Research 4 (May) 253-267. 
Table 1: Data Description and Summary Statistics

\begin{tabular}{|c|c|c|c|c|c|c|c|}
\hline Variable & Definition & $\begin{array}{l}\text { No. } \\
\text { Subjects }\end{array}$ & $\begin{array}{l}\text { No. of } \\
\text { Obs. }\end{array}$ & Mean & $\begin{array}{l}\text { Std. } \\
\text { Dev. }\end{array}$ & Min & Max \\
\hline CE1 & $\begin{array}{l}\text { Customer efficiency measure ("CE1 } \\
\text { squared" is the square term of CE1) }\end{array}$ & 24450 & 224377 & 0 & 1 & -5.59 & 4.97 \\
\hline CE2 & $\begin{array}{l}\text { Alternative customer efficiency measure } \\
\text { (with VRU data) }\end{array}$ & 24450 & 224377 & 0 & 1 & -5.49 & 4.66 \\
\hline CE3 & $\begin{array}{l}\text { Alternative customer efficiency measure } \\
\text { (sample mean proportion weight) }\end{array}$ & 24450 & 224377 & 0 & 1 & -5.07 & 3.56 \\
\hline CE4 & $\begin{array}{l}\text { Alternative customer efficiency measure } \\
\text { (equal weight) }\end{array}$ & 24450 & 224377 & 0 & 1 & -4.28 & 3.87 \\
\hline profit & $\begin{array}{l}\text { Customer profitability (as measured by the } \\
\text { bank) }\end{array}$ & 23089 & 109428 & 9.65 & 117.07 & $-4,562.63$ & $14,062.06$ \\
\hline depart & $\begin{array}{l}1 \text { if customer left the bank and zero } \\
\text { otherwise }\end{array}$ & 24450 & 224377 & .05 & .22 & 0 & 1 \\
\hline Inliabbal & Liability balance (e.g. deposits) & 24450 & 224377 & 8.19 & 2.52 & 0 & 17.43 \\
\hline lnastbal & Asset balance (e.g. loans) & 24450 & 224377 & 2.72 & 4.08 & 0 & 15.13 \\
\hline lninvbal & Investment balance (e.g. mutual fund) & 24450 & 224377 & .62 & 2.37 & 0 & 16.15 \\
\hline lnatm & ATM transactions & 24450 & 224377 & 1.31 & 1.10 & 0 & 5.02 \\
\hline lnvru & VRU transactions & 24450 & 224377 & .92 & 1.40 & 0 & 6.78 \\
\hline Intl & Teller transactions & 24450 & 224377 & 1.26 & .82 & 0 & 5.66 \\
\hline lneb & Internet/online banking transactions & 24450 & 224377 & .40 & .97 & 0 & 6.07 \\
\hline $\operatorname{lninq}$ & Account inquiry transactions (all channels) & 24450 & 224377 & 1.67 & 1.36 & 0 & 6.79 \\
\hline lndep & Deposit transactions (all channels) & 24450 & 224377 & 1.25 & .72 & 0 & 5.66 \\
\hline lnwd & Withdrawal transactions (all channels) & 24450 & 224377 & 1.72 & .85 & 0 & 5.36 \\
\hline $\ln x f r$ & Transfer transactions & 24450 & 224377 & .15 & .42 & 0 & 3.33 \\
\hline tenure & $\begin{array}{l}\text { Length of relationship (years), tenure } 2 \text { is the } \\
\text { square }\end{array}$ & 24450 & 224377 & 9.63 & 7.72 & 0 & 35.52 \\
\hline eb-tenure & $\begin{array}{l}\text { Time since online banking initiated (years), } \\
\text { eb-tenure2 is the square }\end{array}$ & 24450 & 224377 & 2.23 & .93 & 0 & 6.34 \\
\hline age & Customer age, age 2 is the square & 24450 & 224377 & 47.21 & 15.59 & 18 & 90 \\
\hline ATM & $\begin{array}{l}\text { Count of ATMs in customer's home zip } \\
\text { code area }\end{array}$ & 24450 & 224377 & 1.65 & 1.92 & 0 & 14 \\
\hline branch & $\begin{array}{l}\text { Count of bank branches in customers' home } \\
\text { zip code area }\end{array}$ & 24450 & 224377 & 1.13 & 1.42 & 0 & 9.00 \\
\hline web & Has internet banking ( $1=$ yes, $0=$ no $)$ & 24450 & 224377 & 36 & .48 & 0 & 1 \\
\hline gender & Gender ( $1=$ female, $0=$ male) & 24450 & 224377 & .80 & .40 & 0 & 1 \\
\hline comp & Interest in computers ( $1=\mathrm{yes})$ & 24450 & 224377 & .05 & .21 & 0 & 1 \\
\hline children & Has children at home & 24450 & 224377 & \multicolumn{4}{|c|}{$\begin{array}{l}\text { 0-missing (69.25\%); 1-no (11.73\%); 2-yes } \\
(19.02 \%)\end{array}$} \\
\hline married & Primary account holder is married & 24450 & 224377 & \multicolumn{4}{|c|}{$\begin{array}{l}\text { 0-missing (33.18\%); 1-no (33.71\%); } 2 \text {-yes } \\
(33.11 \%)\end{array}$} \\
\hline income & Annual household income (estimated) & 24450 & 224377 & \multirow{2}{*}{\multicolumn{4}{|c|}{$\begin{array}{l}\text { 0-missing }(19.55 \%) \text {; 1-low }(<=\$ 40 \mathrm{k})(19.18 \%) \text {, } \\
\text { 2- medium }(\$ 40 \sim 75 \mathrm{k})(24.87 \%), 3 \text {-high } \\
\text { ( >=\$75k)(26.39\%) } \\
\text { 0-missing }(87.3 \%) \text {; 1-high school, vacation or } \\
\text { technology school (4.54\%), 2-college }(5.06 \%) \text {, } \\
\text { 3-graduate school }(3.1 \%)\end{array}$}} \\
\hline education & Education level of primary account holder & 24450 & 224377 & & & & \\
\hline
\end{tabular}

Each observation ("obs.") is a subject in a month. All variables can potentially vary over time except demographic variables (gender, comp, children, married, income, education), and physical channel availability (ATM, branch). 
Table 2: Channel Use Analysis

\begin{tabular}{|c|c|c|c|c|c|}
\hline & (1) & (2) & (3) & (4) & (5) \\
\hline & $\begin{array}{c}\text { Teller Channel } \\
\text { Intl }\end{array}$ & $\begin{array}{c}\text { VRU Channel } \\
\text { lnvru }\end{array}$ & $\begin{array}{c}\text { ATM Channel } \\
\text { lnatm }\end{array}$ & $\begin{array}{c}\text { ACH Channel } \\
\text { lnach }\end{array}$ & $\begin{array}{c}\text { Online Banking } \\
\text { Ineb }\end{array}$ \\
\hline Ininq & $\begin{array}{c}.050 \\
(.003)^{* *} \\
\end{array}$ & $\begin{array}{c}.832 \\
(.004)^{* *} \\
\end{array}$ & $\begin{array}{c}.130 \\
(.004)^{* *} \\
\end{array}$ & & $\begin{array}{c}.181 \\
(0.010)^{* *} \\
\end{array}$ \\
\hline lnwd & $\begin{array}{c}.153 \\
(.006)^{* *}\end{array}$ & & $\begin{array}{c}.612 \\
(.006)^{* *}\end{array}$ & $\begin{array}{c}.331 \\
(.005)^{* *}\end{array}$ & $\begin{array}{c}.124 \\
(0.016)^{* *}\end{array}$ \\
\hline lndep & $\begin{array}{c}.436 \\
(.007)^{* *} \\
\end{array}$ & & $\begin{array}{c}.129 \\
(.008)^{* *}\end{array}$ & $\begin{array}{c}.454 \\
(.006)^{* *} \\
\end{array}$ & \\
\hline $\ln x f r$ & & & $\begin{array}{c}.452 \\
(.012)^{* *}\end{array}$ & & $\begin{array}{c}.737 \\
(0.023)^{* *}\end{array}$ \\
\hline age & $\begin{array}{c}.021 \\
(.001)^{* *}\end{array}$ & $\begin{array}{c}-.006 \\
(.002)^{* *}\end{array}$ & $\begin{array}{c}-.009 \\
(.002)^{* *} \\
\end{array}$ & $\begin{array}{c}-.007 \\
(.001)^{* *}\end{array}$ & $\begin{array}{c}-.026 \\
(0.005)^{* *}\end{array}$ \\
\hline age2 & $\begin{array}{c}-.0002 \\
(.00001)^{* *}\end{array}$ & $\begin{array}{c}.00005 \\
(.00002)^{* *}\end{array}$ & $\begin{array}{c}-.00001 \\
(.00002)\end{array}$ & $\begin{array}{c}.0001 \\
(.00001)^{* *}\end{array}$ & $\begin{array}{c}.0002 \\
(.00005)^{* *}\end{array}$ \\
\hline comp & $\begin{array}{c}-.005 \\
(.020) \\
\end{array}$ & $\begin{array}{l}-.035 \\
(.026) \\
\end{array}$ & $\begin{array}{c}.010 \\
(.025) \\
\end{array}$ & $\begin{array}{c}.010 \\
(.020) \\
\end{array}$ & $\begin{array}{c}.093 \\
(.062) \\
\end{array}$ \\
\hline college & $\begin{array}{c}-.033 \\
(.027) \\
\end{array}$ & $\begin{array}{c}-.052 \\
(.035) \\
\end{array}$ & $\begin{array}{c}.087 \\
(.031)^{* *}\end{array}$ & $\begin{array}{l}.006 \\
(.024)\end{array}$ & $\begin{array}{l}-.048 \\
(.086)\end{array}$ \\
\hline graduate & $\begin{array}{c}-.123 \\
(.030)^{* *}\end{array}$ & $\begin{array}{c}-.123 \\
(.040)^{* *}\end{array}$ & $\begin{array}{c}.153 \\
(.036)^{* *}\end{array}$ & $\begin{array}{c}.018 \\
(.029) \\
\end{array}$ & $\begin{array}{l}.060 \\
(.101)\end{array}$ \\
\hline tenure & $\begin{array}{c}-.012 \\
(.00173)^{* *}\end{array}$ & $\begin{array}{c}.015 \\
(.002)^{* *}\end{array}$ & $\begin{array}{c}-.008 \\
(.002)^{* *}\end{array}$ & $\begin{array}{c}.025 \\
(.002)^{* *}\end{array}$ & $\begin{array}{l}-.010 \\
(.006)\end{array}$ \\
\hline tenure2 & $\begin{array}{c}.0004 \\
(.00006)^{* *}\end{array}$ & $\begin{array}{c}-.0003 \\
(.00007)^{* *}\end{array}$ & $\begin{array}{c}-.00001 \\
(.00007) \\
\end{array}$ & $\begin{array}{c}-.0006 \\
(.00005)^{* *}\end{array}$ & $\begin{array}{c}.0002 \\
(.0002) \\
\end{array}$ \\
\hline eb_tenure & $\begin{array}{c}-.053 \\
(.013)^{* *} \\
\end{array}$ & $\begin{array}{c}.101 \\
(.020)^{* *}\end{array}$ & $\begin{array}{c}.019 \\
(.015) \\
\end{array}$ & $\begin{array}{c}.102 \\
(.012)^{* *}\end{array}$ & $\begin{array}{c}-.365 \\
(.025)^{* *} \\
\end{array}$ \\
\hline eb-tenure2 & $\begin{array}{c}.003 \\
(.002) \\
\end{array}$ & $\begin{array}{c}-.030 \\
(.004)^{* *}\end{array}$ & $\begin{array}{c}-.014 \\
(.003)^{* *}\end{array}$ & $\begin{array}{c}-.017 \\
(.002)^{* *}\end{array}$ & $\begin{array}{c}.093 \\
(.005)^{* *}\end{array}$ \\
\hline ATM & $\begin{array}{c}-.008 \\
(.003)^{* *}\end{array}$ & $\begin{array}{l}-.006 \\
(.004)\end{array}$ & $\begin{array}{c}.020 \\
(.003)^{* *}\end{array}$ & $\begin{array}{l}-.004 \\
(.003)\end{array}$ & $\begin{array}{l}-.011 \\
(.009)\end{array}$ \\
\hline branch & $\begin{array}{c}-.011 \\
(.003)^{* *}\end{array}$ & $\begin{array}{c}-.015 \\
(.005)^{* *}\end{array}$ & $\begin{array}{c}.032 \\
(.004)^{* *}\end{array}$ & $\begin{array}{c}-.021 \\
(.003)^{* *} \\
\end{array}$ & $\begin{array}{c}.031 \\
(.011)^{* *}\end{array}$ \\
\hline web & $\begin{array}{c}-.128 \\
(.022)^{* *}\end{array}$ & $\begin{array}{c}-.379 \\
(.0274)^{* *}\end{array}$ & $\begin{array}{c}-.191 \\
(.024)^{* *}\end{array}$ & $\begin{array}{c}.132 \\
(.021)^{* *}\end{array}$ & \\
\hline Med-income & $\begin{array}{l}-.005 \\
(.012)\end{array}$ & $\begin{array}{l}-.025 \\
(.014)\end{array}$ & $\begin{array}{c}.002 \\
(.013)\end{array}$ & $\begin{array}{c}.026 \\
(.010)^{*}\end{array}$ & $\begin{array}{c}.133 \\
(.036)^{* *}\end{array}$ \\
\hline High-income & $\begin{array}{l}-.020 \\
(.012) \\
\end{array}$ & $\begin{array}{c}.071 \\
(.015)^{* *} \\
\end{array}$ & $\begin{array}{c}.006 \\
(.013) \\
\end{array}$ & $\begin{array}{c}.022 \\
(.011)^{*}\end{array}$ & $\begin{array}{c}.281 \\
(.036)^{* *} \\
\end{array}$ \\
\hline gender & $\begin{array}{c}-.091 \\
(.018)^{* *}\end{array}$ & $\begin{array}{c}-.023 \\
(.023) \\
\end{array}$ & $\begin{array}{c}.044 \\
(.020)^{*}\end{array}$ & $\begin{array}{c}.045 \\
(.016)^{* *}\end{array}$ & $\begin{array}{c}.155 \\
(.055)^{* *}\end{array}$ \\
\hline children & $\begin{array}{c}.059 \\
(.016)^{* *}\end{array}$ & $\begin{array}{l}-.005 \\
(.021) \\
\end{array}$ & $\begin{array}{l}-.015 \\
(.019) \\
\end{array}$ & $\begin{array}{c}.021 \\
(.015) \\
\end{array}$ & $\begin{array}{c}-.143 \\
(.053)^{* *}\end{array}$ \\
\hline married & $\begin{array}{c}-.057 \\
(.011)^{* *}\end{array}$ & $\begin{array}{c}.039 \\
(.014)^{* *}\end{array}$ & $\begin{array}{c}.106 \\
(.013)^{* *}\end{array}$ & $\begin{array}{c}-.044 \\
(.010)^{* *}\end{array}$ & $\begin{array}{l}-.021 \\
(.036)\end{array}$ \\
\hline $\begin{array}{l}\text { Dummy } \\
\text { Variables }\end{array}$ & State, Month & State, Month & State, Month & State, Month & State, Month \\
\hline Observations & 224377 & 224377 & 224377 & 224377 & 224377 \\
\hline R-squared & .26 & .63 & .53 & .46 & \\
\hline
\end{tabular}


regression coefficients are standardized. Three decimal places are used unless to have more decimal places is necessary (e.g. the coefficients and standard errors of "age2" and "tenure2").

Table 3: Customer Efficiency Measure and Correlates

\begin{tabular}{|c|c|c|c|c|}
\hline & (1) & (2) & (3) & (4) \\
\hline & $\begin{array}{c}\text { Customer-specific } \\
\text { Weights } \\
\text { CE1 }\end{array}$ & $\begin{array}{c}\text { VRU Included } \\
\text { CE2 }\end{array}$ & $\begin{array}{c}\text { Sample Mean } \\
\text { Weights } \\
\text { CE3 }\end{array}$ & $\begin{array}{c}\text { Equal Weights } \\
\text { CE4 }\end{array}$ \\
\hline age & $\begin{array}{l}-.003 \\
(.002) \\
\end{array}$ & $\begin{array}{c}-.005 \\
(.002)^{*} \\
\end{array}$ & $\begin{array}{c}-.021 \\
(.00207)^{* *} \\
\end{array}$ & $\begin{array}{c}-.018 \\
(.002)^{* *} \\
\end{array}$ \\
\hline age2 & $\begin{array}{l}-.00003 \\
(.00002)\end{array}$ & $\begin{array}{l}-.00002 \\
(.00002)\end{array}$ & $\begin{array}{c}.00009 \\
(.00002)^{* *}\end{array}$ & $\begin{array}{c}.00006 \\
(.00002)^{* *}\end{array}$ \\
\hline comp & $\begin{array}{l}-.002 \\
(.027) \\
\end{array}$ & $\begin{array}{l}-.014 \\
(.027) \\
\end{array}$ & $\begin{array}{c}.034 \\
(.029) \\
\end{array}$ & $\begin{array}{c}.023 \\
(.029) \\
\end{array}$ \\
\hline college & $\begin{array}{l}.044 \\
(.036)\end{array}$ & $\begin{array}{l}.024 \\
(.037)\end{array}$ & $\begin{array}{c}.107 \\
(.039)^{* *}\end{array}$ & $\begin{array}{c}.116 \\
(.039)^{* *}\end{array}$ \\
\hline graduate & $\begin{array}{c}.105 \\
(.042) *\end{array}$ & $\begin{array}{l}.061 \\
(.043) \\
\end{array}$ & $\begin{array}{c}.235 \\
(.043)^{* *}\end{array}$ & $\begin{array}{c}.235 \\
(.043)^{* *}\end{array}$ \\
\hline tenure & $\begin{array}{c}.006 \\
(.002)^{*}\end{array}$ & $\begin{array}{c}.016 \\
(.002)^{* *}\end{array}$ & $\begin{array}{c}.015 \\
(.003)^{* *}\end{array}$ & $\begin{array}{c}.022 \\
(.002)^{* *}\end{array}$ \\
\hline tenure2 & $\begin{array}{c}-.0003 \\
(.00007)^{* *}\end{array}$ & $\begin{array}{c}-.0006 \\
(.00007)^{* *}\end{array}$ & $\begin{array}{c}-.0006 \\
(.00009)^{* *}\end{array}$ & $\begin{array}{c}-.0008 \\
(.00008)^{* *}\end{array}$ \\
\hline eb_tenure & $\begin{array}{c}.092 \\
(.020)^{* *}\end{array}$ & $\begin{array}{c}.114 \\
(.021)^{* *}\end{array}$ & $\begin{array}{c}.093 \\
(.018)^{* *}\end{array}$ & $\begin{array}{c}.114 \\
(.018)^{* *}\end{array}$ \\
\hline eb-tenure2 & $\begin{array}{c}-.028 \\
(.004)^{* *}\end{array}$ & $\begin{array}{c}-.033 \\
(.004)^{* *}\end{array}$ & $\begin{array}{c}-.021 \\
(.003)^{* *}\end{array}$ & $\begin{array}{c}-.025 \\
(.003)^{* *}\end{array}$ \\
\hline web & $\begin{array}{c}-.528 \\
(.029)^{* *}\end{array}$ & $\begin{array}{c}-.446 \\
(.029)^{* *}\end{array}$ & $\begin{array}{c}-.304 \\
(.031)^{* *}\end{array}$ & $\begin{array}{c}-.383 \\
(.0309)^{* *}\end{array}$ \\
\hline Dummy Variables & State, Month & State, Month & State, Month & State, Month \\
\hline Observations & 224377 & 224377 & 224377 & 224377 \\
\hline R-squared & .07 & .05 & .04 & .05 \\
\hline
\end{tabular}

Each column represents a separate regression. The column header is the dependent variable. Huber-White robust standard errors are shown in parenthesis. ${ }^{*}-\mathrm{p}<.05,{ }^{* *}-\mathrm{p}<.01$. Dummy variables for missing data (education) are also included (not shown). All models are significant with $\mathrm{p}<.001$. None of the regression coefficients are standardized. Three decimal places are used unless to have more decimal places is necessary (e.g. the coefficients and standard errors of "age2” and "tenure2"). 
Table 4: Customer Efficiency and Profit

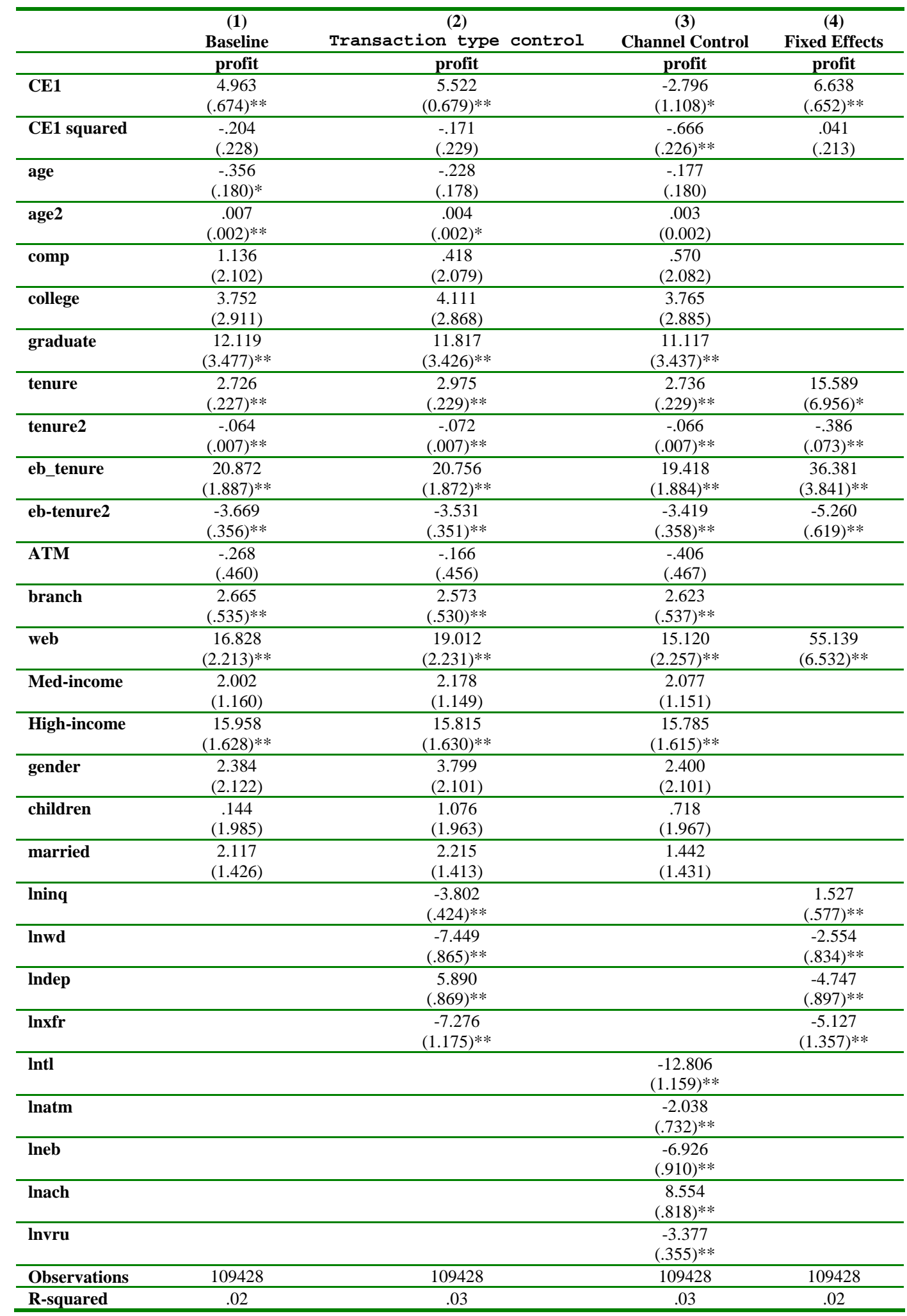

Each column represents a separate regression. The column header is the dependent variable. Huber-White robust standard errors are in parenthesis except for the fixed effects regression. * $-\mathrm{p}<.05$, ** $-\mathrm{p}<.01$. A constant and dummy variables for missing data (income, gender, married, education) are also included (not shown), state and month are also included. Sample size is reduced since 
profit is only available every two months. All models are significant with $\mathrm{p}<.001$. None of the regression coefficients are standardized. Three decimal places are used unless to have more decimal places is necessary (e.g. the coefficients and standard errors of "age2" and "tenure2”). 
Table 5: Customer Efficiency and Attrition

\begin{tabular}{|c|c|c|c|}
\hline & $\begin{array}{c}(1) \\
\text { Baseline }\end{array}$ & $\begin{array}{c}(2) \\
\text { Transaction type } \\
\text { control }\end{array}$ & Channel (3) \\
\hline & depart & depart & depart \\
\hline CE1 & $\begin{array}{l}-.067 \\
(.024) * *\end{array}$ & $\begin{array}{l}-.034 \\
(.025)\end{array}$ & $\begin{array}{l}-.187 \\
(.036) * *\end{array}$ \\
\hline CE1 squared & $\begin{array}{l}.035 \\
(.008) * *\end{array}$ & $\begin{array}{l}.026 \\
(.008) * *\end{array}$ & $\begin{array}{l}.025 \\
(.009) * *\end{array}$ \\
\hline age & $\begin{array}{l}-.049 \\
(.010) * *\end{array}$ & $\begin{array}{l}-.048 \\
(.010) * *\end{array}$ & $\begin{array}{l}-.047 \\
(.010) * *\end{array}$ \\
\hline age2 & $\begin{array}{l}.0003 \\
(.0001) * *\end{array}$ & $\begin{array}{l}.0003 \\
(0.0001)^{* *}\end{array}$ & $\begin{array}{l}.0003 \\
(.0001) * *\end{array}$ \\
\hline comp & $\begin{array}{l}-.139 \\
(.199)\end{array}$ & $\begin{array}{l}-.134 \\
(.199)\end{array}$ & $\begin{array}{l}-.135 \\
(.199)\end{array}$ \\
\hline college & $\begin{array}{l}-.066 \\
(.226)\end{array}$ & $\begin{array}{l}-.065 \\
(.225)\end{array}$ & $\begin{array}{l}-.069 \\
(.226)\end{array}$ \\
\hline graduate & $\begin{array}{l}.252 \\
(.254)\end{array}$ & $\begin{array}{l}.265 \\
(.255)\end{array}$ & $\begin{array}{l}.254 \\
(.255)\end{array}$ \\
\hline tenure & $\begin{array}{l}-.081 \\
(.013) * *\end{array}$ & $\begin{array}{l}-.070 \\
(.014) * *\end{array}$ & $\begin{array}{l}-.073 \\
(.014) * *\end{array}$ \\
\hline tenure2 & $\begin{array}{l}.002 \\
(.0006)^{* *}\end{array}$ & $\begin{array}{l}.001 \\
(.0006) *\end{array}$ & $\begin{array}{l}.001 \\
(.0006)^{*}\end{array}$ \\
\hline eb_tenure & $\begin{array}{l}.247 \\
(.094) * *\end{array}$ & .258 (.094)** & $\begin{array}{l}.251 \\
(.095) * *\end{array}$ \\
\hline eb-tenure2 & $\begin{array}{l}-.039 \\
(.019) *\end{array}$ & $\begin{array}{l}-.039 \\
(.0192)^{*}\end{array}$ & $\begin{array}{l}-.038 \\
(.019)\end{array}$ \\
\hline$\overline{\text { ATM }}$ & $\begin{array}{l}.016 \\
(.02)\end{array}$ & $\begin{array}{l}.017 \\
(.020)\end{array}$ & $\begin{array}{l}.011 \\
(.021)\end{array}$ \\
\hline branch & $\begin{array}{l}.060 \\
(.023) * *\end{array}$ & $\begin{array}{l}.066 \\
(.023) * *\end{array}$ & $\begin{array}{l}.057 \\
(.023)^{*}\end{array}$ \\
\hline web & $\begin{array}{l}.089 \\
(.143)\end{array}$ & $\begin{array}{l}.128 \\
(.144)\end{array}$ & $\begin{array}{l}.132 \\
(.146)\end{array}$ \\
\hline Med-income & $\begin{array}{l}-.001 \\
(.083)\end{array}$ & $\begin{array}{l}.010 \\
(.083)\end{array}$ & $\begin{array}{l}.008 \\
(.083)\end{array}$ \\
\hline High-income & $\begin{array}{l}-.084 \\
(.088)\end{array}$ & $\begin{array}{l}-.059 \\
(.088)\end{array}$ & $\begin{array}{l}-.066 \\
(.088)\end{array}$ \\
\hline gender & $\begin{array}{l}-.115 \\
(.118)\end{array}$ & $\begin{array}{l}-.094 \\
(.118)\end{array}$ & $\begin{array}{l}-.102 \\
(.119)\end{array}$ \\
\hline children & $\begin{array}{l}-.221 \\
(.144)\end{array}$ & $\begin{array}{l}-.235 \\
(.144)\end{array}$ & $\begin{array}{l}-.218 \\
(.144)\end{array}$ \\
\hline married & $\begin{array}{l}.561 \\
(.092) * *\end{array}$ & $\begin{array}{l}.550 \\
(.092) * *\end{array}$ & $\begin{array}{l}.526 \\
(.093) * *\end{array}$ \\
\hline Ining & & $\begin{array}{l}.029 \\
(.024)\end{array}$ & \\
\hline Inwd & & $\begin{array}{l}-.034 \\
(.033)\end{array}$ & \\
\hline lndep & & $\begin{array}{l}-.223 \\
(.038) * *\end{array}$ & \\
\hline $\ln x f r$ & & $\begin{array}{l}-.117 \\
(.069)\end{array}$ & \\
\hline Intl & & & $\begin{array}{l}-.216 \\
(.047) * *\end{array}$ \\
\hline lnatm & & & $\begin{array}{l}.063 \\
(.033)\end{array}$ \\
\hline Ineb & & & $\begin{array}{l}-.119 \\
(.039) * *\end{array}$ \\
\hline Inach & & & $\begin{array}{l}-.116 \\
(.041) * *\end{array}$ \\
\hline lnvru & & & $\begin{array}{l}.019 \\
(.021)\end{array}$ \\
\hline Dummy Variables & Month, State & Month, State & Month, State \\
\hline Observations & 224377 & 224377 & 224377 \\
\hline
\end{tabular}

Each column represents a separate logistic regression. The column header is the dependent variable. Huber-White robust standard errors are in parenthesis. ${ }^{*}-\mathrm{p}<.05,{ }^{*}-\mathrm{p}<.01$. Dummy variables for missing data (income, gender, married) are also included (not 
shown). All models are significant with $p<.001$. None of the regression coefficients are standardized. Three decimal places are used unless to have more decimal places is necessary (e.g. the coefficients and standard errors of "age2" and "tenure2").

Table 6: Customer Efficiency and Product Use

\begin{tabular}{|c|c|c|c|c|c|c|}
\hline & $\begin{array}{l}\text { (1) } \\
\text { Liabilities: } \\
\text { OLS }\end{array}$ & $\begin{array}{l}\text { (2) } \\
\text { Liabilities: } \\
\text { Fixed Effects }\end{array}$ & $\begin{array}{l}\text { (3) } \\
\text { Assets: } \\
\text { OLS }\end{array}$ & $\begin{array}{l}\text { (4) } \\
\text { Assets: } \\
\text { Fixed } \\
\text { Effects }\end{array}$ & $\begin{array}{l}\text { (5) } \\
\text { Investments: } \\
\text { OLS }\end{array}$ & $\begin{array}{l}\text { (6) } \\
\text { Investments: } \\
\text { Fixed Effects }\end{array}$ \\
\hline & Inliab & Inliab & lnast & Inast & Ininv & Ininv \\
\hline CE1 & $\begin{array}{l}.393 \\
(.018)^{* *}\end{array}$ & $\begin{array}{l}.645 \\
(.005)^{* *}\end{array}$ & $\begin{array}{l}.050 \\
(.0231)^{*}\end{array}$ & $\begin{array}{l}.286 \\
(.008)^{* *}\end{array}$ & $\begin{array}{l}-.006 \\
(.01)\end{array}$ & $\begin{array}{l}.042 \\
(.004)^{* *}\end{array}$ \\
\hline CE1 squared & $\begin{array}{l}-.235 \\
(.006)^{* *}\end{array}$ & $\begin{array}{l}-.236 \\
(.002)^{* *}\end{array}$ & $\begin{array}{l}-.050 \\
(.008)^{* *}\end{array}$ & $\begin{array}{l}-.100 \\
(.003)^{* *}\end{array}$ & $\begin{array}{l}-.020 \\
(.004)^{* *}\end{array}$ & $\begin{array}{l}-.011 \\
(.001)^{* *}\end{array}$ \\
\hline age & $\begin{array}{l}.018 \\
(.005)^{* *}\end{array}$ & & $\begin{array}{l}.100 \\
(.008)^{* *}\end{array}$ & & $\begin{array}{l}.015 \\
(.005)^{* *}\end{array}$ & \\
\hline age2 & $\begin{array}{l}.00002 \\
(.00005)\end{array}$ & & $\begin{array}{l}-.001 \\
(.00007)^{* *}\end{array}$ & & $\begin{array}{l}-.00009 \\
(.00005)\end{array}$ & \\
\hline comp & $\begin{array}{l}.056 \\
(.065) \\
\end{array}$ & & $\begin{array}{l}-.12 \\
(.132) \\
\end{array}$ & & $\begin{array}{l}.097 \\
(.096) \\
\end{array}$ & \\
\hline college & $\begin{array}{l}.162 \\
(.084)\end{array}$ & & $\begin{array}{l}.125 \\
(.169)\end{array}$ & & $\begin{array}{l}.024 \\
(.118)\end{array}$ & \\
\hline graduate & $\begin{array}{l}.466 \\
(.094) * *\end{array}$ & & $\begin{array}{l}.087 \\
(.195)\end{array}$ & & $\begin{array}{l}.013 \\
(.137)\end{array}$ & \\
\hline tenure & $\begin{array}{l}.146 \\
(.006)^{* *}\end{array}$ & $\begin{array}{l}.785 \\
(.032)^{* *}\end{array}$ & $\begin{array}{l}.131 \\
(.010)^{* *}\end{array}$ & $\begin{array}{l}-.389 \\
(.050) * *\end{array}$ & $\begin{array}{l}.069 \\
(.006)^{* *}\end{array}$ & $\begin{array}{l}-.051 \\
(.022)^{*}\end{array}$ \\
\hline tenure2 & $\begin{array}{l}-.003 \\
(.0002)^{* *}\end{array}$ & $\begin{array}{l}.0001 \\
(.0006) \\
\end{array}$ & $\begin{array}{l}-.003 \\
(.0004)^{* *}\end{array}$ & $\begin{array}{l}-.012 \\
(.001)^{* *}\end{array}$ & $\begin{array}{l}-.002 \\
(.0002) * *\end{array}$ & $\begin{array}{l}.007 \\
(.0004)^{* *}\end{array}$ \\
\hline eb_tenure & $\begin{array}{l}.037 \\
(.043)\end{array}$ & $\begin{array}{l}.211 \\
(.032)^{* *}\end{array}$ & $\begin{array}{l}.254 \\
(.083)^{* *}\end{array}$ & $\begin{array}{l}.320 \\
(.051)^{* *}\end{array}$ & $\begin{array}{l}.136 \\
(.052)^{* *}\end{array}$ & $\begin{array}{l}.015 \\
(.023)\end{array}$ \\
\hline eb-tenure2 & $\begin{array}{l}.005 \\
(.008)\end{array}$ & $\begin{array}{l}.031 \\
(.005)^{* *}\end{array}$ & $\begin{array}{l}-.026 \\
(.016)\end{array}$ & $\begin{array}{l}-.045 \\
(.008)^{* *}\end{array}$ & $\begin{array}{l}-.016 \\
(.010)\end{array}$ & $\begin{array}{l}.010 \\
(.004)^{* *}\end{array}$ \\
\hline ATM & $\begin{array}{l}-.005 \\
(.010)\end{array}$ & & $\begin{array}{l}-.007 \\
(.017)\end{array}$ & & $\begin{array}{l}-.009 \\
(.012) \\
\end{array}$ & \\
\hline branch & $\begin{array}{l}.114 \\
(.012)^{* *}\end{array}$ & & $\begin{array}{l}-.027 \\
(.021)\end{array}$ & & $\begin{array}{l}.036 \\
(.016)^{*}\end{array}$ & \\
\hline web & $\begin{array}{l}.211 \\
(.066)^{* *}\end{array}$ & $\begin{array}{l}.947 \\
(.054)^{* *}\end{array}$ & $\begin{array}{l}.348 \\
(.129)^{* *}\end{array}$ & $\begin{array}{l}.755 \\
(.086)^{* *}\end{array}$ & $\begin{array}{l}.167 \\
(.072)^{*}\end{array}$ & $\begin{array}{l}.086 \\
(.039)^{*}\end{array}$ \\
\hline Med-income & $\begin{array}{l}.451 \\
(.037)^{* *}\end{array}$ & & $\begin{array}{l}.419 \\
(.068)^{* *}\end{array}$ & & $\begin{array}{l}.160 \\
(.041)^{* *}\end{array}$ & \\
\hline High-income & $\begin{array}{l}.867 \\
(.038)^{* *}\end{array}$ & & $\begin{array}{l}.674 \\
(.072)^{* *}\end{array}$ & & $\begin{array}{l}.369 \\
(.046)^{* *}\end{array}$ & \\
\hline female & $\begin{array}{l}-.033 \\
(.063)\end{array}$ & & $\begin{array}{l}.322 \\
(.100)^{* *}\end{array}$ & & $\begin{array}{l}-.027 \\
(.064)\end{array}$ & \\
\hline children & $\begin{array}{l}-.300 \\
(.052)^{* *}\end{array}$ & & $\begin{array}{l}.005 \\
(.104)\end{array}$ & & $\begin{array}{l}-.074 \\
(.070)\end{array}$ & \\
\hline married & $\begin{array}{l}-.232 \\
(.036)^{* *} \\
\end{array}$ & & $\begin{array}{l}-.557 \\
(.068)^{* *} \\
\end{array}$ & & $\begin{array}{l}.031 \\
(.04) \\
\end{array}$ & \\
\hline $\begin{array}{l}\text { Dummy } \\
\text { Variables }\end{array}$ & Month, State & Month, State & Month, State & Month, State & Month, State & Month, State \\
\hline Observations & 224377 & 224377 & 224377 & 224377 & 224377 & 224377 \\
\hline R-squared & .17 & .12 & .07 & .09 & .03 & .05 \\
\hline
\end{tabular}


Each column represents a separate regression. The column header is the dependent variable. Huber-White robust standard errors are in parenthesis except for the fixed effects regressions. ${ }^{*}-\mathrm{p}<.05,{ }^{* *}-\mathrm{p}<.01$. A constant and dummy variables for missing data (income, gender, married, education) are also included (not shown), state and month are also included. All models are significant with $\mathrm{p}<.001$. None of the regression coefficients are standardized. Three decimal places are used unless to have more decimal places is necessary (e.g. the coefficients and standard errors of "age2" and “tenure2”). 